\title{
BRIC - BRASIL, RÚSSIA, ÍNDIA, CHINA E ÁFRICA DO SUL: UMA PERSPECTIVA
}

\author{
BRIC - BRAZIL, RUSSIA, INDIA, CHINA AND SOUTH AFRICA: A PERSPECTIVE
}

Paulo Borba Casella*

\begin{abstract}
Resumo:
O espaço de cooperação possível e todavia em construção entre as novas potencias emergentes dos assim chamados? BRIC?, que reúnem Brasil, Rússia, Índia, China e África do Sul, representa uma perspectiva nova para a ordenação do mundo globalizado do século XXI. Mais de duas décadas depois do final da guerra fria (1949-1989), que condicionou durante mais de uma geração a operação dos eixos de poder e de relações internacionais do conjunto do mundo, a atual situação de crises internas nos Estados Unidos e na União Europeia os tornam menos aptos e menos presentes no exterior e criaram vazio de governança global, que pode ser desempenhado por esse grupo de países, que representam metade da população do planeta.
\end{abstract}

Palavras-chave: Cooperação econômica. Relações Internacionais. BRIC. Brasil. Rússia. Índia. China. África do Sul.

\begin{abstract}
:
The possibility of a cooperation framework among the emerging powers of the socalled BRIC countries? Brazil, Russia, India, China and South Africa? presents a new perspective for ordering the globalized world of the 21st. century. More than two decades after the end of the Cold War (1949-1989), that conditioned during more than a generation the operation of the power axis and the international relations in the world at large, the present situation of internal crisis in the United States and the European Union render same less capable and less prepared to be present abroad and created a vacuum of global governance, which may be performed by this group of countries, representing half of the population of the entire planet.
\end{abstract}

Keywords: Economic cooperation. International relations. BRIC. Brazil. Russia. India. China. South Africa.

It is now common knowledge that there have been systems of international law in ancient China, India, Greece and the Moslem Empire, among others. Once continuous forms of contact between different communities are established, rules ordering these relations are bound to develop.

George ABI SAAB (1962)

Professor Titular de Direito Internacional Público e Vice-diretor da Faculdade de Direito da Universidade de São Paulo; professor visitante das Universidades de Paris-Sorbonne (2007), Panthéon-Assas (2006), Estrasburgo (2005), e Macau, China (2007, 2008, 2009, 2010). Presidente da Comissão de Publicação da Revista da Faculdade de Direito da Universidade de São Paulo.

1 ABI-SAAB, Georges. The newly independent states and the rules of international law: an outline. Howard Law Journal, v. 8, p. 96, 1962. 
It is China, India, Egypt and other ancient Eastern states which should be considered the birthplace of international law.

E. A. KOROVIN (1959)²

Within our Western purview a considerable body of knowledge which should tend to broaden our horizon and make us realize that there is much that is not new under the sun or exclusively European or Occidental.

HERSHEY $(1926)^{3}$

In the course of time there grew up a network of Sinoforeign relations that roughly correspond in East Asia to the international order that grew up in Europe.

John King FAIRBANK $(1968,1970)^{4}$

Introdução: Inserção internacional e cooperação no mundo pós-moderno

Todos os países e cada um deles têm de cuidar de suas respectivas inserções internacionais. Tão clara a percepção de tal necessidade, como variados são os caminhos possiveis para a implementação: são múltiplos e variados os modelos que podem ser utilizados.

Aceita a premissa da necessidade da busca de inserção internacional, começarão as variações em torno do tema de como e com quais parceiros deva esta ser prioritariamente buscada. Aí se inserem incontáveis análises e mudanças de perspectivas, ocorridas nos últimos vinte anos.

Ao mesmo tempo, todos e cada um dos países, no mundo pós-moderno, tem de se conscientizar dos imperativos da cooperação internacional. Isso se faz imperativo em mundo no qual a interdependência pauta de modo cada vez mais acentuado as relações interestatais.

Isto faz que os países tenham ao mesmo tempo de cuidar de suas agendas internas e internacionais, e as exigências estruturais e operacionais de cada uma destas. Soberania, inserção internacional, desenvolvimento econômico e social, equilíbrio de câmbio e pagamentos, cooperação internacional em assuntos os mais variados nem

2 KOROVIN, E. A. International law (edited by the Institute of Law of the Academy of Sciences of the USSR, Moscow, 1959, also translated into Chinese, Beijing, 1959, p. 23.

3 HERSHEY in his book review of VISWANATHA, S. International law in Ancient India. AJIL, v. 20, p. 426, 1926.

4 FAIRBANK, John King. A preliminary framework. In: FAIRBANK, J. K. (Ed.). The Chinese world order: traditional China's foreign relations. Cambridge, Ma.: Harvard Univ. Press, (C) 1968. $2^{\text {nd }}$ printing, 1970, p. 1-19, cit. p. 2): "although, as we shall see, international or interstate do not seem appropriate terms for it. We prefer to call it the Chinese world order" 
sempre são fáceis de compatibilizar, mas simultaneamente estarão presentes para todos e cada um dos estados.

De tudo quanto se fez e se escreveu, antes do final do período da guerra fria (1949-1989) pouco sobreviveu, sem parecer história antiga, no sentido de tratar de mundo que não mais existe, este se conhece pela experiência vivida no passado, ou a partir de leituras, mas trata-se de contexto desligado de nossa realidade presente. E, no entanto, somente se passaram vinte anos, desde a queda do muro de Berlim, do final da União soviética e do término do período de confrontação, latente ou aberta, como alternadamente se fez, entre os blocos ideológicos, que tiveram a pretensão de alinhar o mundo durante as quatro décadas que se seguiram ao fim da segunda guerra mundial.

Guerra se grafa em minúsculas porquanto não se podem admitir como os marcos principais ordenadores do mundo e dos períodos de análise e de exame deste. Como tendo a escrever 'estado' em minúsculas, para tormento dos revisores das editoras, que tendem a querer corrigir.

Aliás, estaria em tempo de se economizarem maiúsculas no português contemporâneo do Brasil. Em inglês, "I" - eu - é sempre escrito com maiúscula; em alemão todos os substantivos; em francês quase nunca, mas sempre "État" aparece em maiúscula; em português do Brasil, flutua muito o uso. Qual deve ser o critério para nortear o uso de tal destaque?

O exame da perspectiva BRIC de cooperação e do papel que pode esta ter no mundo pós-moderno propõe examinar a questão crucial da busca de inserção internacional e as perspectivas de cooperação no mundo pós-moderno.

Para tanto se terá de considerar a situação atual do discurso e da prática de Brasil, Rússia, Índia, China e África do Sul diante do imperativo da cooperação internacional. O que não é pouco, mas deverá nortear o exame das matérias a ser desenvolvido nos capítulos seguintes.

As lições da história podem ser úteis, quando aprendidas, é o tema seguinte, pois esta verdade, quase tautológica, tantas vezes parece ser esquecida. Por isso cabe ser lembrada.

O exame da situação do Brasil especialmente na sua busca de inserção internacional será objeto de constante atenção. Isso ocorre desde antes de nossa independência, e tem permanecido em pauta desde então.

A Rússia, em menos de cem anos passou por transformações extraordinárias, desde a santa Rússia dos Czares, com séculos de história e de evolução, desde os primórdios, até a Revolução de 1917. A URSS (1920-1989) se põe como tentativa de reformular a ordem social e política não somente interna, como mundial, com os resultados que teve, para dar lugar à Rússia de hoje, que corre atrás do prejuízo: deixou de ser superpotência, e se vê rebaixada a condição na qual tem de novamente lutar pela qualidade e pela abrangência 
de sua inserção internacional. O conjunto continua em mutação, e toda avaliação deve ser feita com cuidado.

Não menores foram e são as transformações em curso na Índia, ao doce sabor da flutuação, entre tradição e inovação, desde a independência, em 1947, passando por todas as transformações até o momento presente. Este gigante de gente e de pretensões tem, todavia, graves problemas estruturais a solucionar.

Ainda mais extensas e surpreendentes são as transformações ocorridas na China. Nesse sentido, proponho o historiador SIMA QIAN, clássico da cultura e da tradição chinesa, como possível guia para a orientação das relações internacionais, da China com o mundo, no contexto pós-moderno.

Ainda grandes transformações pautam a África do Sul, com considerável mudança da percepção internacional na África do Sul, e desta pelo mundo. Em vinte anos deixa de ser vilão da história, quase unanimemente execrada internacionalmente pelo anterior regime do apartheid ${ }^{\overline{1}}$ como controvertida e conturbada política oficial do país, que prevaleceu de 1948 até a redemocratização da África do Sul, em curso desde o início dos anos 1990, para se tornar país inovador, com repercussão possível no continente africano e além deste.

Diante desse quadro esboçado, em seus estados componentes, indago a possibilidade de construção de novo modelo nas relações internacionais. O que já se encontra em curso, em algumas vertentes, e todavia por ser feito, em outras.

Como não poderia deixar de ser, o Direito Internacional tem papel crucial a desempenhar no contexto pós-moderno, em função da revisão dos modelos vigentes no mundo, nos planos institucional e normativo. Esta vertente jurídica se inscreve na convicção de que a diversidade cultural e humana pode trazer soluções inovadoras para a regulação ordenada do mundo, desde que se evitem os erros e as condicionantes do passado.

Logicamente qualquer tentativa de compreensão terá de se pautar pelo indispensável estudo de cada uma destas civilizações, complexas e tão diferentes entre si. Devem ser consideradas, em sua história, sua cultura, sua economia, suas relações internacionais, sua relação com o Direito Internacional e a política, tanto interna como internacional, de cada uma delas, para a seguir ser possível fazer qualquer análise de conjunto e das possíveis interações entre estas.

A percepção do conjunto dos BRIC e do impacto da institucionalização possível desse novo modelo relacional, no cenário do mundo não pode ser menosprezada.

5 Apartheid era a abreviatura de uso corrente para designar aparte outwikkeling, ou desenvolvimento separado, como pretendia o cínico programa do aparteísmo, defendido pelo Partido Nacionalista, vitorioso em 1948. 
Existe contribuição possível, além dos interesses respectivos dos estados participantes, para redesenhar o mapa do mundo e das relações internacionais nas próximas décadas.

O cansaço dos modelos antigos é patente. Está na hora de encetar novas receitas.

\section{Brasil, Rússia, Índia, China e África do Sul entre visões do interesse nacional e o imperativo da cooperação internacional}

A maior parte das sociedades europeias ultrapassou há muito tempo a fase do estado, mas os princípios, que regulam as suas relações exteriores ainda são os mesmos, que seriam aplicáveis e racionais somente nessa fase da evolução social. ${ }^{6}$ Essa análise "inovadora" foi publicada em 1886.

Ante o imperativo da busca de inserção internacional, no mundo de hoje, a perspectiva BRIC de cooperação pode significar mutação de alcance mundial - Brasil, Rússia, Índia e China podem gerar e se beneficiar de modelo novo, e sem precedentes de gestão de interesses compartilhados - quer nas relações entre estes, como em relação ao mundo exterior. A estes quatro pode somar-se a África do Sul, o que pode parecer possível sob certas condições, mas não se acha, todavia, plenamente configurado, como se verá.

A perspectiva BRIC não diz respeito somente aos países participantes, com interesses recíprocos e desafios semelhantes a serem enfrentados, por todos e cada um destes, em suas respectivas inserções internacionais, como feixes de sistemas bilaterais, mas, igualmente, no sentido de ação conjunta e atuação colegiada que, ao operar de modo ordenado e eficiente, poderá redesenhar a cooperação no mundo pós-moderno. Esta decorre do cansaço das fórmulas e modelos tradicionais.

Logicamente ao se considerar BRIC trata-se de considerar, sobretudo os próprios estados interessados, em suas interações bilaterais e regionais, mas não se pode nem se deve esquecer que este pode significar mutação relevante para o mundo pósmoderno. A base para a compreensão do tema será o dado de que a perspectiva BRIC não se esgota no uso interno, nem pode permanecer voltada somente para si mesma.

A efetividade de laços, que entre estes países se construa, pode alterar o equilíbrio mundial, em fase, como a presente, na qual esse equilíbrio mundial se vai redesenhar. Está em construção o chamado mundo multipolar. Se este é necessário e bemvindo, ainda se encontra em processo de configuração: ainda não está desenhado.

$\overline{6}$ NOVICOW, J. La politique internationale. Intr. Eugène Veron. Paris: Felix Alcan, 1886. livre III, chap. IV 'la politique ancienne et la politique internationale de l'avenir', p. 334-393, cit. p. 334): «La plus grande partie des sociétés européennes ont dépassé depuis longtemps la phase de l'état, mais les principes qui règlent leurs relations extérieures sont encore restés les mêmes qui sont applicables et rationnels seulement dans cette phase de l'évolution sociale.» 
Desnecessário dizer quanto mudou o mundo, desde o fim da guerra fria (1949-1989) - que os 'analistas internacionais' falharam fragorosamente em prever - e quanto todos se questionam sobre os rumos possíveis de ordenação deste. Assim nos vemos, depois de (felizmente) ter soçobrado o hegemonismo unilateralista estadunidense, na década mais sombria do Direito Internacional, marcada pelos desgovernos do mundo (período Bush 2000-2008), com uso unilateral da força, violações dos princípios fundamentais do Direito Internacional dos direitos humanos, e ataques contra a jurisdição e a implementação do Tribunal penal internacional. E essa lista, infelizmente, poderia ser consideravelmente estendida. O que mostra a extensão do trabalho que estaria a ser feito pela Gestão Obama (a partir de 2009). Infelizmente, imerso o país em crise econômicofinanceira que, pela sua gravidade, tem sido equiparada à grande depressão, que se seguiu à crise de 1929, vê-se recrudescimento de nacionalismo e de conservadorismo na política interna estadunidense, que deve deter ou ao menos arrefecer o andamento da política reformista que encetara Obama.

O estrondoso fracasso militar, político e econômico do primarismo unilateralista da anterior gestão estadunidense é o suficiente para deixar claro que não pode ser este o modelo de ordenação do mundo, que pode ser desejável. Exceto para os mais empedernidos arautos do realismo político, e defensores da força nas relações internacionais, que desconsideram qualquer espaço e valor para os princípios e as normas de Direito Internacional, ficou claro que o mundo é mais vasto e mais complexo do que qualquer potência - repito, qualquer potência - possa, hoje, pretender controlar. Se morreu o unilateralismo, trata-se, contudo, de saber qual multilateralismo se pode pretender operar.

$\mathrm{O}$ forte retrocesso institucional e operacional do sistema institucional e normativo internacional, ocorrido nos primeiros anos da presente década, até 2008 , sob nefanda influência do modelo obsoleto, propugnado, com uso da força e do poderio militar e econômico do grande irmão americano, se percebe tanto mais claramente, porquanto essa década sucede a outra, que se pautara por excelente registro de funcionamento e de progressos na ordem internacional, como fora a década de 1990. O contraste é eloqüente e nos faz lamentar o desvario de poder, de desastrosas conseqüências, pelo qual o mundo continuará a pagar nos próximos anos: os maus frutos ainda terão de ser colhidos.

$\mathrm{Na}$ anterior década (1991-2000), na esteira do desfazimento da confrontação leste-oeste, que regera o eixo principal de ordenação do mundo durante os quarenta anos da assim chamada guerra fria (1949-1989), se viram consideráveis progressos no sentido da ordenação politicamente multilateral do mundo, institucionalmente regida pelo Direito Internacional. Avanços institucionais e operacionais consideráveis tinham sido feitos no sistema institucional e normativo internacional durante esse período.

Alguns dados simples podem permitir avaliar os estragos feitos nesta década: baste mencionar que a primeira guerra do golfo (1991) se decidira na Organização 
das Nações Unidas, as operações de paz tinham sido decididas no âmbito do Conselho de Segurança da ONU, os dois tribunais penais internacionais, para Ruanda e para a ex-Iugoslávia, tinham sido adotados também pelo Conselho de Segurança, e estes representaram antecedentes diretos, para o posterior surgimento do Tribunal penal internacional, nos termos do Estatuto de Roma, de 1998, instaurado desde 2002. Entra em vigor, em 1994, a Convenção das Nações Unidas sobre o direito do mar, que fora celebrada em 1982, e desde 1996 foi instaurado e opera o Tribunal internacional para o direito do mar, com sede em Hamburgo, e essa lista, de avanços institucionais, normativos e de procedimentos de implementação do Direito Internacional, no contexto pós-moderno, pode ser consideravelmente ampliada.

É preciso perceber as conseqüências para se recusar, firme e definitivamente, o hegemonismo agressivo, é preciso lutar pelo direito nas relações internacionais, é preciso deixar de lado as análises, lastreadas na política de poder (power politics), sobretudo quando emanadas de países periféricos, para se pensar modelos novos de ordenação das relações mundiais, e dentre tudo isso que se trata de fazer, neste momento de reestruturação de alianças no mundo, pode inscrever-se a "perspectiva BRIC de cooperação" Sua exata configuração vai ser, a partir de agora, desenhada.

A proposta de cooperação entre Brasil, Rússia, Índia, China-com a possível participação da África do Sul - pode ser inovadora, nos seus conceitos balizadores, no seu conteúdo e nos seus desdobramentos, na prática. É possível reinventar o modelo de relação entre estes estados, livres das amarras que parecem vincular outros quadros regionais.

Claramente estes países não são, nem se devem pretender melhores do que os outros. Não se trata de dizer que sejam intrinsecamente mais 'virtuosos' ou mais alinhados pelo direito, na ordenação das relações internacionais, mas trata-se, sim, de conceber que ao cuidarem de seus respectivos interesses, mas ordenados em conjunto multilateral, podem mudar o equilíbrio do mundo. Não se trata de reeditar o "concerto europeu" (1814-1914), que teve seu papel, ao tempo e no contexto no qual foi criado e operou de modo significativo, para redesenhar o equilíbrio na Europa, após os vinte e poucos anos de turbulência, que tinham marcado as guerras da Revolução francesa e do período de Napoleão Bonaparte (1792-1815).

Se as mudanças no equilíbrio do mundo já se encontram em acelerado processo de configuração, as percepções e análises de tais transformações todavia não se fazem sentir de modo pleno. Hesitam os analistas a respeito dos modelos ${ }^{8}$ em gestação:

SEDOUY, Jacques-Alain de. Le concert européen - aux origines de l'Europe (1814-1914). Paris: Fayard, 2009.

8 KHANNA, Parag. The second world - empires and their influence in the new global order. New York: Random House, 2008. 
é mais fácil trabalhar com o exame de fatos consumados, mas aí se terá perdido a configuração da novidade.

Não poderá o quadro de análise do mundo pós-moderno balizar-se por parâmetros herdados do passado, porquanto mudou inexoravelmente o teatro do mundo nas últimas décadas. Não mais se fale em globalização, ${ }^{9}$ enquanto tal - ninguém mais agüenta a repetição de tais discursos - mas, cabe perquirir quais sejam os meios e modos de fazer que esta opere de modo adequado. Se isto for possível. Mas, como não pode a globalização ser evitada, é melhor que esta funcione, ${ }^{10}$ do modo menos danoso para a vida e a dignidade humana, para a cultura, para o meio ambiente ${ }^{11}$ e para a continuidade da vida inteligente no planeta. Quanto ainda é incipiente a compreensão da necessidade e da extensão da preservação da vida e dos recursos do planeta.

Tais percepções podem, justamente, contribuir para a compreensão das mutações em curso no mundo. E estas se terão de refletir em novas configurações de relações entre os estados.

Daí poderá resultar a construção de modelos, inovadores e pragmáticos, e estes, ao mesmo tempo, em que levem em conta dados da história, como da economia, da política como do direito e das relações internacionais, podem permitir evitar repetir erros e infames escolhas, consideradas aceitáveis ou mesmo legítimas, no tempo pretérito, utilize esses dados para, em lugar de perpetuar desmandos do passado, contribuir para construir equilíbrio, novo e eficaz, que se possa alinhar pelos parâmetros de caráter sinalagmático, que confira durabilidade à relação, como se paute por premissas que se fazem mais e mais necessárias, como o Direito Internacional do desenvolvimento sustentável, e a proteção internacional dos direitos fundamentais.

A perspectiva BRIC de cooperação pode ser uma resposta possível, e esta pode ser dada pela prática. Pode ser inovação relevante, para que o mundo se alinhe por princípios, de respeito mútuo, e de equilíbrio de interesses nas trocas comerciais, diversamente do que historicamente pautou e, tødavia, em considerável e ominosa medida, ainda pauta o conjunto das relações internacionais e das trocas comerciais entre os estados. Estes países, quatro ou cinco, conforme se insira ou não plenamente a África do Sul, neste momento da história e da conjuntura internacional presente, podem reinventar o modelo

9 HOBSBAWN, Eric. Globalização, democracia e terrorismo. Trad. José Viegas. São Paulo: Cia. das Letras, 2007.

10 STIGLITZ, Joseph E. Making globalization work. New York: Norton, 2006. cit. p. xvi e 24: "All human institutions are imperfect, and the challenge for each is to learn from the successes and failures" e em vista disso, ressalta a necessidade de se colocar mais peso em valores, como a cultura, o meio ambiente e a própria vida: "weight on values, like culture, the environment and life itself."

"HUGHES, J. Donald. An Environmental History of the World - Humankind's changing role in the community of life. London and New York: Routledge, $1^{\text {st }}$. publ., 2001, reprinted 2004). 
de relação de cooperação entre eles, e essa reformulação, além deles, pode ter reflexos nas respectivas inserções internacionais, como além destes, para o conjunto do mundo.

Não existem alinhamentos automáticos, nem modelos pré-estabelecidos, na "perspectiva BRIC" em relação à cooperação possível entre Brasil, Rússia, Índia, China e, talvez, também a África do Sul. Estes podem desenvolver os seus próprios quadros, nos quais insiram modelos de trocas comerciais, como de intercâmbio cultural, os mais variados. Não tendo cargas do passado, nas relações entre si, podem esses países estabelecer parâmetros para o futuro, na assim chamada "perspectiva BRIC de cooperação"

O que o torna interessante, é o fato de que "BRIC" ainda é modelo por ser inventado. $\mathrm{E}$ isso está em curso, e interessa não somente a cada um dos integrantes da sigla, como teria reflexos para o conjunto do mundo, e, mesmo, se poderia entrever a construção de novos formatos de inserção internacional, mas, cabe, simultaneamente, deixar claro o que não seria quase tão útil como determinar o que pode ser:

- antes de tudo, cabe deixar claro que se trata de modelo de cooperação - atuação coordenada, por meio de mecanismos intergovernamentais, sem necessidade de criação de estruturas institucionais comuns - e onde se tenha clareza com relação às consequências de tal formato, quanto ao seu conteúdo e os seus desdobramentos - esse patamar da cooperação se inscreve entre dois patamares, de um lado, o patamar mínimo da mútua abstenção -- modelo antigo de relações entre estados - e, de outro, o patamar máximo da integração : não se trate de mais nem de menos que de cooperação, no sentido estrito do termo, que da economia migra e se aplica também nas relações internacionais: pode haver remoção de barreiras comerciais, pode e deve haver ação internacional coordenada, mas cada estado conservaria a sua soberania e a sua independência, e liberdade de ação, em todas as áreas nas quais, expressamente, não se assumam compromissos comuns;

segundo dado crucial da perspectiva BRIC será o fato de que não há imperativos nem da história nem da geografia - o que pode ser marcante em outros processos regionais, como no caso europeu, exemplo notável, de integração que deu certo, sobretudo quando contraposto aos cenários das várias tentativas no contexto interamericano, que nunca deram resultados verdadeiramente eficazes, nem duradouros: o BRIC não existe, não decorre da história, não se coaduna com a geografia, este está para ser inventado; é modelo que se constrói na medida do interesse recíproco, e da mútua conveniência dos estados interessados, não é imperativo filosófico kantiano, nem decorre de necessidades conceituais; é modelo a ser instaurado empiricamente, é escolha estratégica, e este pode vir a pautar a política externa e as relações internacionais de cada um desses estados, e a partir destes, pode também mudar o equilíbrio do mundo; 
terceiro dado será a falta de modelo predeterminado: não há formato necessário, nem suficiente para o comportar. Está este "modelo BRIC" para ser implantado. Mas, não por isso será necessário "reinventar a roda", no sentido de que os modelos de cooperação econômica já há muito são conhecidos e praticados, inclusive por esses países, em suas relações econômicas internacionais, e pode inscrever-se, em qualquer ponto do espectro, entre o máximo de coesão institucional que marca a União Européia, e o mínimo, que pauta a configuração da APEC - a Cooperação Econômica da Ásia-Pacífico. ${ }^{12}$ Ambos tem os seus papéis a desempenhar. Mas aqui se trata de considerar o fenômeno novo, que se pode inscrever além e ao lado destes.

Entre um extremo e outro, BRIC pode ordenar-se, segundo qualquer formato, desde que funcione: não existem modelos 'certos' e modelos 'errados' na economia, mas existem os modelos que funcionam ou não. Por isso, é preciso compreender o que possa ser, e o que não deve ser este espaço de cooperação. O formato é a cooperação, tal como se conhece e se pratica, há décadas; a inovação estará no conteúdo, e este ainda terá de ser determinado, pelos próprios estados interessados;

- quarto dado a ser apontado são as semelhanças de momento histórico e de condições relativas de inserção internacional de cada um dos BRIC - com semelhanças tão marcantes, quanto as diferenças - mas onde esforço de captação e de exame das realidades permitirá concluir que se trate de conjunto com mais semelhanças, do que as diferenças superficiais poderiam fazer imaginar: existe trabalho de captação da realidade, esforço humanista de compreensão do outro, e quadro de dados a ser exercitado segundo conceitos e técnicas jurídicas, sobretudo do direito comparado e do direito internacional, para se compreender o quanto os une e o que os separa, e por trás das diferenças aparentes, quanto existe que possa ser passível de ser consolidado, como alianças entre esses estados: basta ver rapidamente quanto mudou cada um desses cinco países, nos últimos vinte ou trinta anos e projetar quais podem ser os passos, para os próximos vinte ou trinta;

finalmente, BRIC não precisa ter agregados, vivendo de favor, em quartos dos fundos da casa, acoplados aos conteúdos que interessam substancialmente - nem deve isso ser esperado, de uns em relação aos outros, nesse quadro; não vejo espaço para cláusulas de favorecimento de parceiros menores ou derrogações temporárias em favor

12 CASELLA, P. B. Integration in the Americas: an overview. Yearbook of European Law, Oxford: Clarendon Press, v. 16, p. 405-422, 1996. 
de parceiros menos desenvolvidos: BRIC se põe como eu chamaria, uma "parceria entre grandes", onde cada um exerce e continuaria a exercitar as suas esferas de influência, em suas respectivas regiões e continentes, sem se pautar pelo favor, mas pela eficiência: são todos "maiores e capazes", e estão insertos em suas respectivas realidades e contextos, interno e internacional, com diversas complementaridades a serem exploradas.

As desigualdades regionais podem ser carga considerável para qualquer processo de cooperação internacional. Estas existiram e existem, e foram enfrentadas desde o início da experiência europeia de integração. A União Europeia tem, diante de si, o enorme desafio de trazer os doze últimos ingressantes para o mesmo patamar de eficiência e de efetividade que pautava a vida dos quinze anteriores..$^{13}$ Isso está em curso, mas nessa enorme tarefa, a Europa integrada nos próximos anos, inexoravelmente terá como prioridade a construção da coesão interna, antes de criar laços com outros países e regiões do mundo. A Europa pode ser estudada, pode ser admirada, pode ser criticada, mas não é a nossa prioridade, nem tampouco nós somos a prioridade deles.

As desigualdades regionais são sempre lembradas, também em relação aos países da América do Sul e se conhecem todas as variações possíveis a respeito do tema. Não se pode, nem se deve, contudo, esperar que o sócio financiador dessa recuperação de desigualdades seja o Brasil, porquanto este tem também as suas graves desigualdades internas por enfrentar e por resolver, e não seria nem legal nem legítimo que o faça de modo benévolo, pelos vizinhos, em detrimento da pobreza e da exclusão social, dentro da própria casa. Por isso, considero estar na hora de repensar a integração regional. Como mais adiante se considera.

Construirão os BRIC algo em comum, na medida em que, a todos e a cada um deles convenha. Mas, qualquer parceria, como qualquer relação entre pessoas, precisa pautar-se pela lealdade e, entre estados, também pela legalidade internacional. Sem o que, qualquer relação se torna insustentável.

Quando se fala em cooperação, na "perspectiva BRIC" se pode pensar em modelo, antes cultural que geográfico - porquanto geograficamente, três dos cinco estados estão geograficamente no 'hemisfério norte' - mas que, nesse modelo, isso se dê por meio de conceitos e de mecanismos nos quais poderiam ser evitadas distorções conceituais e operacionais, que, historicamente marcaram os modelos tradicionais, de mútua abstenção,

13 A respeito, v. CASELLA, P. B. Ampliação da União Européia: a Europa Central se integra. In: MARQUES, Claudia Lima; ARAUJO, Nadia de. O novo direito internacional: estudos em homenagem a Erik Jayme. Rio de Janeiro: Renovar, 2005. p. 723-743. 
esses mesmos modelos que, durante muito tempo, pautaram as relações internacionais. ${ }^{14}$ Criticar os modelos antigos é mais fácil do que criar novos modelos.

Esse modelo inovador, e pautado pela não-exploração de uns em detrimento de outros, normalmente é chamado de cooperação sul-sul, ${ }^{15}$ para o distinguir do modelo norte-sul, do rico para o pobre, com tônica de paternalismo, que se reveste de ranço colonialista. ${ }^{16}$ Dizer o que não deve ser parece mais do que dizer o que deveria ser.

O modelo sul-sul se pautaria pelo equilíbrio e pelo caráter sinalagmático da relação. ${ }^{17}$ Os dados que poderiam parecer aceitáveis para os padrões culturais e políticos do tempo, não mais se podem tolerar no Direito Internacional pós-moderno.

$O$ Direito Internacional da época marcada pelo apogeu colonialista, de 1870 a $1960^{18}$ reflete o contexto histórico e cultural do tempo: as premissas do Direito Internacional têm de ser situadas em relação à época. A descolonização, justamente, assinala novo marco, por volta do ano de $1960 .{ }^{19}$

A mudança do modelo, ${ }^{20}$ em curso desde então, leva a um Direito Internacional, mais consentâneo com o contexto pós-moderno: a mutação histórica precisa se fazer acompanhar de correspondente mutação de modelo institucional. ${ }^{21}$

14 ALEXANDROWICZ, C. H. The Afro-Asian world and the law of nations: historical aspects. RCADI, 1968, t. 123, p. $117-214$.

15 V., por exemplo, MAHIOU, Ahmed. Le cadre juridique de la coopération sud-sud: quelques expériences ou tentatives d'intégration. RCADI, 1993, t. 241, p. 9-194.

16 CHESNEAUX, Jean. A Ásia oriental nos séculos XLX e XX. Trad. Antonio Rangel Bandeira. São Paulo: Pioneira, 1976; mostra as sucessivas investidas do Ocidente na Ásia oriental: uma primeira fase até por volta de 1890 , e uma segunda fase de 1890 até 1937.

17 Ainda em 1888, o Instituto de Direito Internacional adotava o projeto de declaração internacional relativa às ocupações de territórios (1888), em pleno contexto colonialista europeu.

18 KOSKENNIEMI, Martti. The gentle civilizer of nations: the rise and fall of international law (1870-1960) ("Hersch Lauterpacht Memorial Lectures"). Cambridge: University Press, $1^{\text {st }}$ published 2001, reprinted 2005 , cit. p. 504): "solutions to social problems cannot be derived from legal theories"

19 CHARPENTIER, Jean. Autodétermination et décolonisation. In: Le droit des peuples à disposer d'euxmêmes: méthodes d'analyse du droit international - mélanges offerts à Charles Chaumont. Paris: Pedone, 1984. p. 117-133.

20 CHARVIN, Robert. Le droit international tel qu'il a été enseigné: notes critiques de lecture des traités et manuels (1850-1950). In: Le droit des peuples à disposer d'eux-mêmes: méthodes d'analyse du droit international - mélanges offerts à Charles Chaumont. Paris: Pedone, 1984. p. 135-159.

21 CHAUMONT, Charles. Cours général de droit international public. RCADI, 1970, t. 129, p. 333-528, cit. p. 345): «Si le droit classique est en voie de disparition comme phase historique, il n'est pas aboli comme méthode et vision» 
Isso se deu, inicialmente, quando da 'colonização' das Américas. ${ }^{22} \mathrm{E}$ do questionamento a respeito da determinação do título, ${ }^{23}$ segundo o qual poderia tal atividade ser exercida. ${ }^{24}$ Depois se projetaria em relação à África e à Ásia.

Deste anseio e deste quadro de semelhanças e de circunstâncias convergentes, nesta fase da história, desses respectivos centros de poder, se pode avançar para a construção da cooperação entre os BRIC. E desta ideia, em alguns casos e contextos específicos privilegiados, se pode progredir para a construção de relações que possam chegar à integração, ao menos pontual e bilateralmente, em relação a casos específicos, nos quais o interesse compartilhado seja suficientemente forte, para levar à fixação de laços mais coesos, em patamar mais elevado.

Integração não é uma palavra mágica, nem a solução para todos os problemas, internos e externos dos Estados, na busca de inserção internacional competitiva, ou de incremento de balança comercial, porquanto exige patamar consideravelmente elevado de engajamento político e institucional, de interesses compartilhados e de reformulação de conceitos básicos da política, da economia, do sistema jurídico, e da base sócio-cultural, durante mais de uma geração, em esforço voltado para a construção de espaços comuns, como está em curso, no modelo em construção na União Europeia - essa experiência específica é admirável, mas, dificilmente transponível para outros quadrantes. Merece registro, como enorme realização em curso, embora às vezes pareça ser mais admirada fora, do que pelos 500 milhões de 'europeus' nesta engajados: quem está dentro parece enxergar mais as mazelas internas do que a grande obra em gestação, como nunca se fizera antes na história da Europa. Depois de se guerrearem durante séculos, o conjunto da Europa - sem esquecer as matanças, limpeza étnica, genocídio, crimes de guerra, crimes contra a humanidade e atos de agressão, na antiga Iugoslávia, menos de vinte anos atrás - mas, ao menos no interior das fronteiras da Europa integrada, França e Alemanha, por exemplo, que estiveram diretamente envolvidos nas guerras de 1870, 1914-1918 e 1939 1945, desde então tem guerreado mais com palavras do que com exércitos convencionais e uso de força armada. Os danos das guerras de palavras e de ideias políticas, econômicas

22 BOSI, Alfredo. Dialética da colonização. São Paulo: Cia. das Letras, 1992; CASELLA, P. B. Fundamentos do direito internacional pós-moderno. São Paulo: Quartier Latin, 2008, esp. item VI, 'direito, história e cultura', pp. 489-615); DIAMOND, Jared. Guns, germs and steel : the fates of Human societies. With a new afterword about the modern world", (C) 1997, New York : Norton, 1999) ; FERRO, Marc. História das colonizações: das conquistas às independências - séculos XIII a XX. Trad. Rosa Freire D'Aguiar. São Paulo: Cia. das Letras, 1996; ROMANO, Ruggiero. Mecanismos da conquista colonial. Trad. Marilda Pedreira, rev. Vera de Campos TOLEDO. São Paulo: Perspectiva, 1973.

23 Veja-se CASELLA, P. B. Direito internacional dos espaços. São Paulo: Atlas, 2009. cap. I e 29 'evolução do conceito e do tratamento do território no direito internacional', bem como cap. XXIX 'espacialidade e direitos fundamentais : dimensão humana do território'. esp. item 29.1 'dos impérios coloniais ao reconhecimento dos direitos dos povos indígenas').

24 CASELLA, P. B. Direito internacional dos espaços. op. cit., 2009. cap. XXIX. 
e culturais, mesmo se por vezes danosos, não chegam a alcançar patamares equivalentes de destrutividade.

Cabe admirar a Europa, mas não cabe copiá-la: isso nem seria possível, nem, tampouco desejável. As condições são substancialmente diversas.

O processo europeu de convergência política, macro-econômica, histórica, social e cultural em curso é, efetivamente, admirável e merece ser admirado, pela mutação essencial em curso, no seu modelo de ordenação da convivência internacional dos estados neste engajados pelo patamar da integração, mas dificilmente pode este ser copiado ou transposto, para outros continentes, ao menos no espaço de vida útil de uma ou duas gerações, porquanto, em outros quadrantes, são substancialmente diversas as condições políticas, econômicas, legais, sócio-culturais. O modelo europeu de integração é único; foi criado e desenvolvido na Europa, e para a Europa; não serve para os BRIC.

ARússia, por exemplo, em relação à União Europeia, deixa claro ter interesse por parcerias - e estas poderiam mudar, rápida e substancialmente, o equilíbrio político e econômico mundial, pelo tamanho e pela relevância da Rússia e dos compromissos que pode assumir em áreas como o fornecimento de energia para a Europa integrada - para dar somente um exemplo, veja-se o "braço de ferro" entre Rússia e Ucrânia, pelo controle de fornecimento de gás para a Europa - mas a Rússia de hoje, sucessora da santa Rússia dos Czares e do núcleo central de poder da ex-União das Repúblicas Socialistas Soviéticas, a Rússia, como antigo império e ex-potência mundial, deixa igualmente claro não pretender se submeter aos burocratas de Bruxelas e de Estrasburgo. A Rússia, hoje, é menor do que fora a URSS, mas está em processo acelerado de mutação, e esta pode ser alternativa para a construção de parcerias regionais e fora da região europeia, também, porquanto as tratativas com a UE não costumam ser fáceis nem rápidas, como já sabe também o Brasil, e aprendeu o MERCOSUL.

Brasil e MERCOSUL têm tentado acordo comercial com a União Europeia sem resultado. Foram-se exatos dez longos e trabalhosos anos de negociações, terminados em 2004, que acabaram na conclusão, dos dois lados, quanto a estarem os dois lados de acordo, em NÃO estarem de acordo. E nova rodada de negociações está em curso, desde 2005, sem quaisquer resultados palpáveis. Essa é longa história, que não caberia retomar aqui.

Podem os BRIC deixar para trás os modelos do passado, pautados pela exploração, marcante nas relações entre os países norte-sul, este modelo, também, antes cultural, que geográfico. Por sua vez, essa cooperação que pode ser descrita como sulsul - desde que concebida como modelo antes cultural que geográfico - poderia ensejar dar lugar para modelo de trocas e de cooperação internacional, legalmente mais justo, economicamente mais eqüitativo, politicamente mais inovador, porque projeta cada um 
dos cinco países para alianças estratégicas fora da sua região, e do círculo imediato de relações bilaterais diretas.

Este possível modelo eqüitativo de cooperação, ademais, poderia ser modelo a ser considerado e aplicado, por outros integrantes da comunidade dos estados, ao menos mais alguns, se não como um todo. Tal formulação se harmoniza, perfeitamente, com certa concepção da natureza jurídica do modelo de cooperação internacional, que daria lugar a relações internacionais, baseadas sobre caráter específico: exprime a convicção de que aquelas regras de regência da cooperação têm caráter construtivo. E podem ser úteis na medida em que a todos e a cada um gerem resultados.

Fica, na cooperação, para trás a mera convivência, ou mútua abstenção, como modelo herdado de outras eras, e dá lugar a modelo novo, baseado na cooperação, e isto, progressivamente se estenderia, mesmo a estados que não tivessem expressamente reconhecido esse modelo como tal, ou seja, a demonstração do caráter universal poderia ser considerada como adquirida, mesmo quando não ficasse estabelecido que o modelo de cooperação foi expressamente reconhecido, como tal, por todos os estados, sem exceções. Desejável, porém ainda está por ser construído.

Uma coisa é afirmar, que seja tal modelo desejável, outra será conseguir seja este aplicado como tal, nas relações internacionais, inclusive, e muito especificamente, entre estados que, em determinado tempo (histórico) e contexto (cultural), foram, cada um deles, objeto de exploração e de tratamento desigual, por parte dos que então se consideravam como titulares das premissas fundadoras da assim chamada "comunidade internacional dos estados, como um todo" a matriz européia ocidental, que constituiu o núcleo histórico do Direito Internacional, que se projetou no passado, para fora da Europa, para o continente americano, entre o final do século XVIII - independência dos Estados Unidos - e o primeiro quarto do século XIX - com a independência das antigas colônias da Espanha e de Portugal nas Américas, e depois, na segunda metade do século XIX, se estende para o Oriente, passando a incluir o então existente Império otomano, a China, o Japão, a antiga Pérsia (atual Irã), e mais alguns estados. De modo bastante seletivo, e por vezes desigual. Curiosamente, é mais fácil criticar os outros do que se renovar a si mesmo.

Logicamente seria tanto penoso quanto temerário pretender fazer caber a história, a cultura, a política, a economia, e as complexas sociedades de cada um destes países, bem como as suas múltiplas e não menos complexas interações possíveis, no corpo desta exposição. Por outro lado, alguns desses dados são vitais para a compreensão das distintas realidades que pautam esses países, e como as pessoas, os estados também são marcados pelas respectivas histórias, e se nunca podemos nos livrar disso, pode ser instigante encetar, em três quartos de hora, a apresentação do que pode ser a proposta BRIC de cooperação internacional, e desta exposição inicial suscitar reflexões e instigar novos enfoques. 
Justamente interessante a "perspectiva BRIC de cooperação" por ser esta inovadora, não se ter de pautar por modelos já conhecidos e experimentados, e poder agregar conteúdos se e na medida em que os respectivos estados estejam nisso interessados. Podem e devem inovar os países, nessa inovadora configuração de relações internacionais e experimentação de novas fórmulas de cooperação, com conteúdos e parâmetros a serem, de comum acordo, determinados. Nos próximos cinco, dez, vinte, ou quem sabe, trinta anos. No espaço de vida útil de uma geração pode ter mudado ainda mais o mundo, em relação ao que mudou nesses últimos vinte ou trinta anos.

Este desafio de configuração de modelo de relações internacionais, na perspectiva dos BRIC, se põe como possibilidade rica de insuspeitados desdobramentos e reformulação do sistema mundial, plena de inexploradas potencialidades: este não faria sentido, nem deveria ser somente "remédio de uso interno" mas teria dimensão e desdobramentos internacionais inexoráveis. Pode ser elemento para a configuração de novo modelo relacional no mundo.

E estes dados não somente estão ao alcance de nossas mãos e de nossas mentes, como, em boa parte, constitui processo já em curso. E se for conhecido, poderá ser mais bem captado, e permitirá que se façam as escolhas estratégicas adequadas, para que possa dar os frutos mais eficazes.

As lições da história podem ser úteis, quando são aprendidas. Mas, nem sempre será fácil esse aprendizado. E as catastróficas conseqüências que podem advir do desconhecimento das lições da história serão ainda mais graves e devem ser evitadas, a todo custo.

2. As lições da história podem ser úteis, quando aprendidas

O tempo desconfia das coisas construídas sem ele. Isso já advertia Charles de Visscher (1953). ${ }^{25}$

Considerar as lições da história significa ter consciência de que estas podem ser úteis, quando aprendidas. A história, como o direito, não se perfaz na teoria, mas deve combinar a experiência prática e a reflexão teórica, como modo de otimizar o possível impacto positivo de cada uma sobre o mundo e sobre a sociedade dos homens.

As lições da história somente podem ser úteis, quando são aprendidas e são aplicadas. É mais fácil discorrer sobre elas do que aplicá-las. Essa é a linha divisória entre a teoria e a prática. Só que uma não avança muito sem a outra. A interação entre ambas pode ser equilibrada, segundo a combinação de proporção adequada.

25 DE VISSCHER, Charles. Théories et réalités en droit international. Paris: Pedone, 1953: «le temps se méfie des choses construites sans lui. ") 
As lições da história parecem não ter deixado marcas, no sentido de que mesmo no caso desses estados, que foram objeto de exploração e de tratamento desigual, não se ponham de acordo quanto a considerar - e, ainda que o faça em nome de convergência puramente hipotética e formal - que determinadas formas obsoletas das relações internacionais, como, tradicionalmente, estas se entendiam e se praticavam, devem sofrer alteração, em decorrência de visão estratégica, de médio e longo prazo, em lugar da prática convencional. Não há motivo plausível para que fiquem atrelados, esses mesmos estados, a repetir os modelos de exploração e de tratamento desigual, aos quais foram sujeitos no passado.

As relações internacionais, desses Estados, e entre esses Estados, nem sempre se tem pautado por tão altos princípios e anseios. Os estados não são entidades filantrópicas: buscam, sobretudo, os seus próprios interesses; tem populações que precisam ser alimentadas, empregadas, educadas e tem de enfrentar a competição internacional, cada vez mais acirrada.

Não se esperem relações humanitárias. Nem, como dizia, relações filantrópicas. Nem desses cinco estados entre si, nem em relação a outros estados: como exemplificariam o tratamento dado, pela Rússia à carne brasileira, e pela China, à soja brasileira, em passado não tão remoto assim. Os exemplos poderiam ser multiplicados.

Para Oswald Spengler, no seu amplo ensaio sobre a decadência do ocidente (1923, nova ed. 2007), ${ }^{26}$ a consciência do ser a respeito de si mesmo estaria colocada, como dado específico, no que chama de 'civilização ocidental' ou seja, não se colocaria, como tal, nem nas civilizações antigas, nem tampouco, na civilização indiana, ou na chinesa. Seria dado do ocidente atual.

Nem sempre se põe como indispensável, para o ser, que este se saiba, individualmente, como tal. Pode ser criativo o conjunto, pode alcançar resultado de construção relevante, para a história, igualmente, a civilização, que se vê como todo, mais que agregado de individualidades.

Assim, a compreensão dos BRIC terá de passar, primeiro, pela percepção e visão clara de cada um deles, para que se aduzam as interações possíveis. Isso tem de ser programa para algum tempo e pode ser pensado, pelas instituições governamentais e universitárias dos respectivos países: BRIC pode se tornar realidade, quando se inscrever no currículo das universidades e institutos de governo e de pesquisa: um ou mais programas de pós-graduação em BRIC, que permita às novas gerações ser mais precisas e mais focadas no conhecimento e tratamento das realidades desses países tão diversificados. BRIC poderá ser realidade, quando for como tal estudado e praticado. Até ali serão 26 SPENGLER, Oswald. Der Untergang des Abendlandes: Umrisse eine Morphologie der Weltgeschichte.
Düsseldorf: Albatroz, 2007. XVI + 1250 p. 
iniciativas pioneiras, mas serão abstrações, em relação às realidades nacionais, e à aferição dos espaços de interação possíveis entre estas. Será teoria, enquanto permanecer reflexão, que não se inscreva na prática, e não se torne efetiva na vida interna e internacional desses cinco estados e seja percebida como mudança ocorrida, nas relações internacionais dos cinco, por outros estados.

As lições da história aqui se põem não como fim em si mesmas, mas para se perceberem semelhanças e diferenças, sem a clara percepção das quais a construção de modelos compartilhados não poderá ser encetada de maneira eficiente e construtiva. $\mathrm{E}$ isto pode ser apontado em relação a cada um desses países, em rápidas pinceladas.

Poderiam e deveriam incluir programas de história comparada e de análise das culturas dos países envolvidos no processo de cooperação, como de conhecimentos das respectivas línguas, dos respectivos sistemas legais e administrativos nacionais, para permitir o manejo eficiente de tais dados entre os operadores, e pode ampliar a lista. Mas, do que se trata, primacialmente? Cuide-se, sobretudo, de perceber o outro, de ir além das diferenças superficiais, para ver em quais espaços, e sobre quais bases, se pode interagir. Além das aparentes diferenças, quais são as semelhanças básicas, que possam ser compartilhadas e forneçam base segura para a construção de tal relacionamento.

Quando o então jovem Mircea Eliade, da sua Romênia natal, pede a um marajá indiano que lhe ofereça bolsa de estudos de dois anos, para conhecer a cultura e as tradições da Índia, a resposta foi, para padrões ocidentais, no mínimo surpreendente: parecia aceitável, e de fato, mereceu aceitação o projeto, mas que o fizesse por ao menos quatro anos, porquanto em dois não teria tempo suficiente para aprender nada da Índia. ${ }^{27}$

Assim, a "perspectiva BRIC de cooperação" terá de passar pelo conhecimento recíproco das sociedades e das culturas, para que este conhecimento floresça e exista. Não é possível nem viável construir essa relação, nem fazer proliferar as interações possíveis, entre as nossas sociedades, se dependermos de materiais e fontes externas, sobretudo, para saber alguma coisa uns sobre os outros. ${ }^{28}$ Veja quanto existe de publicações e informações sobre cada um dos outros quatro, em livrarias e instituições de pesquisa e de ensino, e se terá a dimensão de quanto falta para que essa premissa seja efetivada.

$\mathrm{O}$ desconhecimento do outro gera conflito, gera preconceitos, gera desencontro, entre visões distintas da vida do ser e da vida da sociedade. Mostra,

27 ELIADE, Mircea. Les promesses de l'équinoxe: Mémoire I 1907-1937. Traduit du roumain par Constantin N. Grigoresco. Paris: Gallimard, 1980, cit. p. 281: «Pour créer, il faut demeurer dans le monde auquel on appartient». Além de numerosos volumes de ensaios e obras sobre história comparada das religiões, escreveu também ELIADE livro clássico sobre Yoga, imortalidade e liberdade e mesmo romance sobre a Índia, Noite bengali. Trad. Maria Leonor Buesco. Lisboa: Ed. Ulisseia, 1961.

28 KAMDAR, Mira. Planeta India: a ascensão turbulenta de uma nova potência global Trad. Cristina Cupertino. Rio de Janeiro: Agir, 2008. O subtítulo da edição original já evidencia o que quero dizer: não é possível ter de compreender o mundo somente a partir da ótica e pelo prisma dos interesses estadunidenses. 
justamente, a necessidade da compreensão de valores e de modelos culturais e sociais. Também como questão da vida (a existência) e da consciência desta, e da questão dos valores. ${ }^{29}$

A existência humana se perfaz na consciência dessa existência, ou seja, há que haver consciência para que se perfaça a existência. Para completar-se a existência, cumpre ocorra igualmente a consciência desta. E a interação entre a vida individual e a vida da sociedade. O mesmo ocorre na vida entre as sociedades, conforme regula o Direito Internacional.

Na relação entre a vida, e a reflexão a respeito da vida, se inscreve o papel da história, da filosofia, como também da política, e do direito, e especificamente, do Direito Internacional. Aí se há de situar também a sociologia, e o conjunto das assim chamadas 'ciências humanas', que se põe em relação direta com a vivência humana. Entenda-se a relação direta da vida e da reflexão sobre a vivência.

Falar em relação direta entre a reflexão e a vida, e na necessidade de interação, entre a vida, e a reflexão sobre a vivência humana, pois, não é, nem pode ser vista, nem compreendida, como fim em si mesma, ou como conjunto abstrato: a reflexão faz parte da vida, e se faz em relação direta com esta, e com esta tem de ser vivida e interpretada. Reflexão, desligada da vida, pode tornar-se desumana, e ser fator de desumanização da vida individual, como da vida em sociedade.

Essa mesma perspectiva, que cada um de nós tem de desenvolver, para sua inserção social e viabilidade de existência pessoal, se põe também nas relações internacionais, na construção de canais e caminhos de relacionamento entre sociedades organizadas, como estados. E no que estes habitualmente praticam, sob o nome de relações internacionais. Isso não é, nem pode ser somente questão de "secos e molhados", nem se resolve em meros "tratados de navegação, comércio e amizade", curiosa terminologia, que até o século XIX e começo do XX se utilizava, para juntar coisas tão díspares. A visão, hoje predominante, tende a ser mais abrangente.

$\mathrm{Na}$ interação indispensável, entre reflexão e vida, se põe grande discussão sobre os modelos de captação e de compreensão da realidade. Curiosamente, não há distância, nem contradição, entre duas dentre as correntes de concepção do sentido da vida: quer se veja em tudo continuidade, quer se veja em tudo a mudança, porquanto simultaneamente tudo muda na vida, ao mesmo tempo em que esta se renova e não deixa de ser o que é, como o único dado certo, de tudo quanto possa a nossa humana percepção compreender e captar, como dado vital central, para que seja a experiência humana avaliada.

29 A respeito, v. CASELLA, P. B. $A B Z$-ensaios didáticos. 2. ed., 2. tir. São Paulo: Imprensa Oficial do Estado, 2008-2009; (especialmente o ensaio 'valores e suas conseqüências', p. 279-298). 
Basicamente podem ser apontados os elementos principais, para permitir a compreensão, dessas diferenças essenciais, quanto ao conteúdo, quanto ao modo de operar, e quanto aos fins, para os quais se destinam. Os modelos culturais podem ser válidos, para construir respostas aos desafios do tempo presente. Mas permanecem modelos, no sentido de que destacam determinados elementos, para permitir conhecer o todo, do qual foram extraídos, mas 'modelos' são esquemas redutores, não são o todo, não abrangem a totalidade da experiência, nem poderiam conter tudo.

Advertia Vicente Licínio Cardoso $(1925)^{30}$ que “a História não deve ser fabricante de elogios ou depósito sebento de críticas póstumas. A História deve explicar : decompor o passado, com a experiência do presente, animado o espírito pela crença do futuro. Elogia quando explica"

A história se põe como matéria de relevância profissional, como qualquer outra, dentre as disciplinas do conhecimento e da ação humanas, mas, acima e ao lado desta atuação 'profissional' cabe considerar o papel da história, como informação e como formação de qualquer ser humano, em sua humana condição. Aí se inscreve dimensão da história, que a todos nos diz respeito e a todos nos interessa. Como tal cabe ser considerada.

As lições da história não somente interessam aos profissionais desta. Para estes profissionais, justamente, a condição pode ser ferramenta para melhor conhecimento técnico, mas também pode ser o mais fácil caminho para se perder a percepção da necessidade e da utilidade dessa que passa a ser antes ferramenta que instrumento de compreensão e de reflexão sobre o mundo.

Não se trata, aqui, de fazer estudo da história, ${ }^{31}$ mas ter como pano de fundo a história, como necessidade de compreensão dos caminhos do mundo. Não se trata de ensaiar tampouco estudo da cultura e da história desta. ${ }^{32}$ Nem tampouco de história

30 CARDOSO, Vicente Licínio. À margem da História do Brasil. Prólogo de Acácio França. $3^{a}$. ed., São Paulo : Nacional / Brasília : INL, 1979, "à margem do Segundo Reinado", pp. 71-126, cit. pp. 112-113).

31 Veja-se o magistral TOYNBEE, Arnold Joseph. A study of History. Abridgement by D. C. Sommerwell. London/New York/Toronto: Oxford U.P., 1949. v. 1-6; 1957: v. 7-10, v. 11 e 12 "Reconsiderations" x+740 p., 1961; ou nas lições, ao mesmo tempo formadores e paradigmas da história, como nos trazem HERÓDOTO e TUCÍDIDES, das quais as edições das Oeuvres complètes (intr. Jacqueline de ROMILLY, HÉRODOTE texte présenté, traduit et annoté par André BARGUET, THUCYDIDE, texte présenté, traduit et annnoté par Denis ROUSSEL, Paris : Gallimard - Pleiade, (C) 1964, impr. 1982), ou, em vernáculo HERÓDOTO. História. Trad. do grego, intr. e notas de Mário da Gama Kury. 2. ed. Brasília: Ed UnB, 1988; e a já citada edição de TUCÍDIDES. História da Guerra do Peloponeso. Tradução do grego, intr. e notas de Adriano da Gama Kury. 3. ed. Brasília: Ed UnB, s/d.

32 BURCKHARDT, Jacob. Kulturgeschichtliche Vorträge. Mit einem Nachwort, herausgegeben von Rudolf MARX“, Stuttgart: Alfred Kröner, 1959, no, posfácio', p. 419-445, comenta o organizador da edição frase de Burckhardt ao jovem Bernard Kluger, em 1874, cit. p. 419) : „Einstweilen geht meine Erfahrung dahin, dass gelehrte Autorschaft eines der ungesundesten und blosses Dozieren (so beschwerlich es sei und so umständlich die dazu gehörigen Studien und Vorbereitungen) eines der gesundesten Metiers auf der Welt ist." Longo caminho da evolução da história da cultura, de clássicos do século xix, como Burckhardt, até clássicos do século xx como Werner Jaeger, com ênfase na sua obra prima, "Paideia: a formação do homem 
enquanto sistema ou ferramenta profissional, mas de contextualização no mundo pósmoderno. Trata-se de situar, no contexto pós-moderno, as lições da história e da cultura.

Toda construção humana tem se reportar ao mundo e ao conceito de mundo, ${ }^{33}$ entendido como tempo (histórico) e contexto (cultural), no qual se inscreva. Tem de estar no mundo, sem necessariamente ser do mundo: tem de tomar como parâmetro a realidade, sob pena de desligar-se desta, mas sem aceitar que essa realidade seja a única realização possível, para o mundo. Assim, também, o Direito Internacional pós-moderno, no contexto cultural e temporal presentes.

Quanto se terá de repensar, a partir das bases e dos conceitos que nos tenha legado o estudo da história de outros tempos, dependerá até onde se queira ou se possa levar a reflexão, sobre esses ensinamentos, a partir do presente.

A construção da história pode ser vista como progressiva, fragmentária e assistemática. Cada uma dessas dimensões pode e deve ser, ainda que brevemente, considerada.

A sucessão de práticas do passado constituiria o legado do que opera nas referências presentes e deve orientar a formulação de condutas de ação futura. Assim podem ser destacados elementos: a tradição, as referências presentes e parâmetros para orientar a ação futura.

Mais vale referir fases ou contextos, e evitar falar a respeito de sucessão de tempo, pois este traz dificuldade, quase insuperável, em sua definição, tornando versada e controvertida questão filosófica, que não caberia pretender retomar aqui, de Santo Agostinho, há mil e quinhentos anos, até os ensaios a respeito, escritos por André ComteSponville, nascido em 1952. Fale-se em elementos: evite-se falar a respeito de sucessão do tempo. Tenha-se presente, somente, que este inevitável e inexoravelmente afeta não somente os seres vivos como os estados e o funcionamento de uns e outros.

As regras são formuladas e aplicadas. São regras no tempo e no lugar em que se vão formando, aplicando, alterando em todas as dimensões e desdobramentos de seu funcionamento. A questão da existência, validade e eficácia, como dimensões distintas que podem ser apontadas.

O caráter de progressividade da história se põe desde o seu surgimento, com Heródoto: a percepção do mundo e dos seres no mundo. E prossegue em Tucídides, Políbio, Tito-Lívio.

grego" (do original Paideia: die Formung des griechischen Menschen, 1936. Trad. de Artur M. Parreira. São Paulo: Martins Fontes, 1979 ou CLARK, Kenneth. Civilização. 2. ed. Trad. Madalena Nicol. São Paulo: Martins Fontes, 1995, até BURKE, Peter. O que é história cultural? Trad. de Sérgio Góes de Paula. Rio de Janeiro: Jorge Zahar, 2005). Entre nós, AZEVEDO, Fernando de. A cultura brasileira: introdução ao estudo de cultura no Brasil. 4. ed., rev. ampl. Brasília: Ed. UnB, 1963.

33 CLAVIER, Paul. Le concept de monde. Paris: PUF, 2000. 
A fragmentação está apresentada na falta de descortino da vida e da visão do outro e se ilustraria na previsão de pretender impor-se sem necessidade de mostrar outros argumentos além do que faz. Daí o sentido das lições da história: o equilíbrio entre a força e a razão é precário, e essa precariedade não é privilégio de nossos dias.

A necessidade de reagir criativamente aos desafios do tempo, ou encetar a decadência, como aconteceu em várias civilizações, é enfatizada por A. Toynbee, na

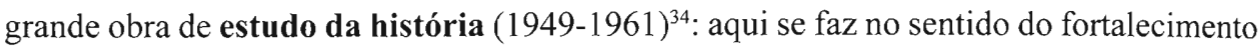
conceitual e institucional das lições da história, para a compreensão do mundo e do contexto pós-modernos.

A alternativa ao pós-moderno? Será a insistência nos modelos antes ensaiados e encetados. Será a permanência nos modelos conhecidos.

As lições da história valem para os indivíduos, como também para os grupamentos humanos. Servem estas para cada um, como também para as coletividades, porquanto todos insertos no mundo e fadados a interagirem no mundo.

No plano humano, as lições da história permitem a captação de duração que vá além da contingência individual de cada ser, no restrito tempo e no limitado espaço de cada um. A perspectiva de desenvolver olhar sub specie aeternitatis.

No plano das coletividades humanas, tradição que remonta a Maquiavel salienta que os governantes, ao obedecerem à razão-de-estado, pretenderão obedecem ao interesse dos seus países. Esses interesses são variados, mas podem ser identificados pela prudência - vista esta como tipo de conhecimento que resulta do senso comum, apoiado na experiência e nas lições da história. Uma vez percebidos e compreendidos, constituem a base que permite a previsibilidade, e com ela as hipóteses de estabilidade ou instabilidade da ordem mundial, através da paz, pela acomodação diplomático-jurídica dos interesses" 35

Significativa tradição no Direito Internacional leva em consideração as dimensões filosóficas da experiência histórica. Desde Vitória e Grócio, aos nossos dias.

Conteúdos historicamente vinculantes não precisaram esperar pelo contexto da crise da pós-modernidade, para surgirem e se consolidarem. Já Vitoria, De potestate civili (1528), asseverava: "o direito das gentes não tem somente força de pacto ou de

34 O magistral TOYNBEE, Arnold. A study of History. Abridgement by D. C. Sommerwell. London/New York/Toronto: Oxford U.P., v. 1-6, 1949, v. 7-10, 1957, v. 11 e 12 "Reconsiderations" x+740 p., 1961), conta edição resumida em português Um estudo da história. (ed. revisada e condensada por A. TOYNBEE e $J$. CAPLAN, trad. Isa Silveira Leal e Miroel Silveira. São Paulo: Martins Fontes / Brasília: Ed. UnB, 1987); mesma conclusão em JAGUARIBE, Hélio (Col.). Um estudo crítico da história. Trad. Sérgio Bath. São Paulo: Paz e Terra, 2001. 2 v. 'conclusões', p. 647-688. É vital para a sobrevivência de qualquer sociedade a capacidade de reagir criativamente aos desafios e de adaptar-se às mudanças contextuais, à medida em que aconteçam.

35 LAFER, C. Da reciprocidade no direito internacional econômico: o convênio do café de 1976. São Paulo: Perspectiva, 1979; Ph. BRAILLARD, Philosophie et relations internationales. Genebra: Institut de Hautes Études Universitaires, 1974. 
convenção entre os homens, mas possui, igualmente, força de lei. O mundo inteiro, na verdade, que, de certo modo, constitui uma república, tem o poder de levar leis justas e ordenadas para o bem de todos, tais como são as do direito das gentes. Conseqüentemente, quando se trata de questões graves, nenhum estado pode se considerar desvinculado do direito das gentes, pois este é colocado pela autoridade do mundo inteiro" 36 Isso deveria ser lembrado com mais ênfase, em nossos dias!

Para J. Barthélemy $(1904)^{37}$ o fato de ser a Espanha a potência dominante da época, bem como a preeminência intelectual de Francisco de Vitória, como espécie de conselheiro do império espanhol, não são estranhos ao fato deste ter necessitado refletir e manifestar-se sobre a relação com os ameríndios, dentre outras questões candentes da época.

Ainda mais pertinente e necessária se torna, quando a discussão sobre a nova ordem mundial tende a substituir a preocupação de jure condito com as propostas de jure condendo ${ }^{38}$ : nada mais concreto, nesse contexto, que os interesses, cuja relevância para a teoria geral do direito, da sociedade, da política e do conhecimento, cujo papel na criação, aplicação e transformação das normas de Direito Internacional público econômico, que regem a vida do café na ordem mundial.

A relação entre a ordenação do estado e a ordenação da convivência entre estados faz haver relação direta entre a teoria geral do estado e o Direito Internacional, na linha de Charles De Visscher (1953). ${ }^{39}$ A concepção e o exercício do poder dentro do estado influenciam profundamente a coordenação de poderes entre os Estados: toda a concepção e prática do Direito Internacional estão ligados a concepção e prática interna dos estados.

Enquanto ensinamento prático, decorrente do senso comum, pode ser colocado paralelo entre os dados da experiência e das lições da história: não contém nem trazem valores intrínsecos, ou conteúdos precisos - funcionam na medida em que sejam aceitos. Alinham ensinamentos, que podem ser inspiradores para os participantes do sistema, podem ter desdobramentos, segundo as regras do jogo - se perfazem na medida em que se observe o 'play by the rules', jogar conforme as regras - e nisso se esgotam :

36 VITORIA, Francisco de. Political writings. Eedited by Anthony Pagden e Jeremy Lawrance. "Cambridge texts in the history of political thought". Cambridge: UP, 1991, "On civil power" De potestate ciuili (1528), p. 1-44), a mais antiga das Relectiones de VITORIA a ser conservada, e provavelmente a segunda mais antiga, depois deste ter assumido a cátedra de teologia em Salamanca em 7 de setembro de 1526.

37 BARTHÉLEMY, J. François de Vitoria. In: Les fondateurs du droit international: leurs oeuvres, leurs doctrines. Introduction de A. Pillet. Paris: V. Giard \& E. Brière, 1904. p. 1-36.

38 LAFER, C. op. cit., 1979. p. xv-xvi.

39 DE VISSCHER, Charles. Théories et réalités en droit international public. Paris: Pedone, 1953; LAFER, C. op. cit., 1979. cap. I 'as transformações dos estados e do direito internacional público e a regulamentação jurídica da ordem econômica mundial', p. 7-28. 
não são, aqui, vistos como ciência, nem tampouco filosofia, mas são, no todo, construção da prática : se alinham pela experiência.

Não trabalham as lições da história com noções de certo e de errado, de justo e de injusto, trabalham com o que funcione, com o que possa assegurar resultados não são idealistas, são pragmáticas. Deixam registro do que foi feito, não necessariamente do mais adequado.

A história, para os profissionais do direito deve servir para a compreensão que vá adiante da norma positiva existente na atualidade: não se pode entender como se chegou ao que ora existe, sem que se saiba de onde vieram conceitos, institutos e norteados por quais razões. Na linha, por exemplo, de A. Castaldo (2006), ${ }^{40} \mathrm{~J}$. R. Lima Lopes (2002), ${ }^{41}$ J. Habermas $(2000,1998,1996)^{42}$ e J. Gilissen $(1988,1979) .{ }^{43}$

Especificamente em relação ao Direito Internacional algumas referências podem ser úteis: D. Gaurier (2005), ${ }^{44} \mathrm{~S}$. Laghmani $(2003),{ }^{45}$ W. G. Grewe $(2000,1984),{ }^{46}$ W. Gould (1957), ${ }^{47}$ P. Guggenheim (1958). ${ }^{48}$

A história pode e mesmo deve ser base, sem se tornar fim em si mesma. Desse modo, para o profissional jurídico cabe ter a visão da história e suas lições como ferramenta para auxiliar na compreensão da vida e para situar-se nela, como no estudo e na compreensão do direito e evitar a pretensão de 'descobrir' o que já existia.

A perspectiva histórica sirva também para evitar cometer anacronismos, como advertia V. L. Cardoso (1925, nova ed., 1979), ${ }^{49}$ de se "julgar o passado com idéias do presente" - as coisas devem ser entendidas no tempo (histórico) e no contexto (cultural) em que tiveram lugar.

40 CASTALDO, André. Introduction historique au droit. 3. ed. Paris: Dalloz, 2006.

41 LOPES, José Reinaldo Lima. $O$ direito na história: lições introdutórias. São Paulo: Max Limonad, 2000; $2^{\mathrm{a}}$ ed., 2002, esp. o cap. 'as idéias jurídicas do século xvi ao século xviii o direito natural moderno e o iluminismo', p. 177-212).

42 HABERMAS, Jürgen. Après l'état-nation: une nouvelle constellation politique. Trad. Rainer Rochlitz. Paris: Fayard, 2000; HABERMAS, Jürgen. La paix perpétuelle: le bicentenaire d'une idée kantienne. Trad. Rainer Rochlitz. Paris: Cerf, 1996.

43 GILISSEN, John. Introdução histórica ao direito. Trad. A. M. Hespanha e L. M. Macaísta Malheiros. Lisboa: Fund. C. Gulbenkian, 1988.

44 GAURIER, Dominique. Histoire du droit international public. Rennes: PU de Rennes, 2005.

45 LAGHMANI, Slim. Histoire du droit des gens: du jus gentium impérial au jus publicum europaeum. Paris: Pedone, 2003.

${ }^{46}$ GREWE, W. G. Epochen der Völkerrechtsgeschichte. Baden-Baden: Nomos, 1984. Trad. inglesa, The Epochs of international law. Berlin - New York: W. de Gruyter, 2000.

47 GOULD, Wesley. An introduction to international law. New York: Harper \& Brothers, 1957.

48 GUGGENHEIM, P. Contribution à l'histoire des sources du droit des gens. RCADI, 1958, t. 94, p. 1-84.

49 CARDOSO, Vicente Licínio. À margem da História do Brasil. Prólogo de Acácio França. 3. ed. São Paulo: Nacional/Brasília : INL, 1979, "à margem do Segundo Reinado", p. 71-126, cit. p. 114; formula advertência muitas vezes esquecida: "Sendo anacrônica a crítica do passado, com as idéias do presente, é por outro lado lamentável - em história que se respeita - a sonegação de qualquer parte da verdade, para aplauso desmedido aos fatos do passado. E já temos pecado bastante neste assunto". 
O endeusamento da tradição normalmente ocorrerá quando esta, insuficientemente consolidada, para fornecer parâmetros para orientação futura, se põe como abstração, que se planta no vazio, de fatos como de idéias, e traz mais ilusões que conhecimento.

A construção de modelo de cooperação, historicamente mais consentâneo com a relativização das posições no cenário internacional, onde os estados deixam de ser os únicos agentes do sistema internacional, ${ }^{50}$ pode ser legalmente mais justo, e economicamente mais eqüitativo, pode ser concebido, teoricamente, e pode ser posto em prática. Mas exigiria a presença de critérios norteadores, e a convicção de sua necessidade, como de sua adequação. Poderia ser o modelo, para reger a cooperação sul-sul, mas este não ocorrerá por si mesmo: terá de ser construído, para que possa, como tal, ser aplicado.

Pode-se conceber e aplicar modelo, mais adequado, nas trocas e nas relações internacionais? A questão não é mera hipótese acadêmica, mas pode ser dado inovador, para a construção de modelo, mais consentâneo com o mundo, no qual se enfatize o imperativo de conjugar desenvolvimento e sustentabilidade. A construção de Direito Internacional do desenvolvimento sustentável é dado a ser levado em conta pelos estados, tanto nos respectivos planos internos, como também no modelo adotado, para as trocas e as relações internacionais.

Pode-se indagar se e em que medida se terá condição de invocar a aplicação de modelo teórico, baseado no equilíbrio, e no caráter eqüitativo das trocas comerciais, contra estados que, sistematicamente, tenham se oposto a estas, e negado a sua existência como norma de conduta das trocas e das relações internacionais: esse não pode ser modelo, que venha imposto de fora, mas somente pode e deve ser reconhecido por todos os estados, que em tal forma de construção das trocas comerciais e das relações internacionais se engajem com a consciência de ser imperativa a sua adoção, de modo absoluto, e se torna inviável, se diversos estados não forem da mesma opinião. Na linha dessa interpretação, são muitas vezes lembrados os seguintes exemplos de normas imperativas de Direito

so RANJEVA, Raymond. Les organisations non-gouvernementales et la mise en oeuvre du droit international. RCADI, 1997, t. 270, p. 9-105. 
Internacional geral: a proscrição da escravidão, do tráfico de seres humanos, do genocídio ${ }^{51}$ e da agressão. 52

Em razão de absoluta necessidade, está em curso a revisão dos modelos de relações internacionais entre os estados. E a construção de novas redes e parâmetros mais diversificados de estruturação destas.

the state exists for man and not man for the state

\section{Wilfred JENKS (1973) $)^{53}$}

O Direito Internacional pós-moderno acarreta revisão dos modelos institucional e normativo herdados de outras eras. A mutação está em curso e os resultados podem, por vezes, parecer pouco claros. Mas o dado central é o fato de que o modelo antigo tornou-se obsoleto e não mais pode dar conta das necessidades do mundo presente.

Do ponto de vista do Direito Internacional pós-moderno, constata-se que o reconhecimento de normas imperativas, para a determinação de critérios para a conduta dos estados interessa a todos sob, pelo menos, três pontos de vista:

(i)o procedimento técnico convencional não é apto, como tal, nem a estabelecer regras, de conteúdo eqüitativo: estas

SI CASELlA, P. B. Fundamentos do direito internacional pós-moderno. Prólogo de Hugo Caminos. São Paulo: Quartier Latin, 2008, itens i, 'construção do direito internacional e contexto pós-moderno', e ii, 'precisões terminológicas e valorativas', com referência à Convenção para a prevenção e a repressão ao crime de genocídio (Nova York, 1948), cujo art. $2^{\circ}$ determina o entendimento a ser conferido ao termo, para os fins da Convenção : "entende-se por genocídio qualquer dos seguintes atos, cometidos com a intenção de destruir, no todo ou em parte, um grupo nacional, étnico, racial ou religioso, tal como: / (a) assassinato de membros do grupo, / (b) dano grave à integridade física ou mental de membros do grupo, / (c) submissão intencional do grupo a condições de existência que lhe ocasionem a destruição física total ou parcial, / (d) medidas destinadas a impedir os nascimentos no seio do grupo, / (e) transferência forçada de menores do grupo para outro grupo"; bem como o texto da Resolução do Instituto de direito internacional adotada na sessão de Cracóvia, em 26 de agosto de 2005 , sobre La compétence universelle en matière pénale à l'égard du crime de génocide, des crimes contre l'humanité et des crimes de guerre/ Universal criminal jurisdiction with regard to the crime of genocide, crimes against humanity and war crimes (Le texte anglais fait foi. Le texte français est une traduction.) $17^{\mathrm{e}}$. Commission $/ 17^{\mathrm{th}}$. Commission Relator: Christian Tomuschat; v. tb.: DALLARI, Dalmo de Abreu. O genocídio repensado. In: BAPTISTA, L. O.; HUCK, H. M.; P. B. CASELLA. (Org.). Direito e comércio internacional: tendências e perspectivas: estudos em homenagem ao prof. Irineu Strenger. São Paulo: LTr, 1994. p. 463-477; ABELLÁN HONRUBIA, Victoria. La responsabilité internationale de l'individu. RCADI, 1999, t. 280, p. 135-428, sobre o crime de genocídio, esp. p. 320-331, cit. p. 323): a identificação das vítimas é essencial para a caracterização do crime de genocídio, na medida em que o ato se cometa contra determinado indivíduo ou grupo "porque esse ou esses indivíduos eram membros de grupo específico e em razão do fato de pertencerem a tal grupo", de tal forma que "la victime du crime de génocide est le groupe lui-même et non pas seulement l'individu. C'est-à-dire que l'accent est mis sur le caractère 'collectif' du bien juridique protégé"

52 ABELLÁN, V. Honrubia. op. cit., 1999, cap. v, 'la qualification des crime de droit international' item i, 'crime d'agression' p. 309-320); v. tb. Komarnicki, W. La définition de l'agresseur dans le droit international moderne. RCADI, 1949, t. 75, p. 1-114.

53 JENKS, C. Wilfred. Economic and social change and the law of nations. RCADI, 1973, t. 138, p. 455-502, cit. p. 495. 
se constroem a partir da escolha de modelos, da adoção de critérios, para nortear as relações entre estados, segundo o direito internacional público: o tratado que estiver em contradição com os propósitos de construção de modelo mais justo e mais duradouro pode ser revisto ou substituído; esses novos instrumentos podem estar na origem de norma costumeira, como previamente estabelecida, mas é pelo processo de escolha de modelo, comportando o elemento de escolha política, quanto ao conteúdo a ser determinado, que a norma inovadora poderá se colocar, e não em decorrência do mecanismo convencional que a precedeu ou acompanhou;

(ii) a construção desse modelo sul-sul de cooperação, também pode se valer de concepção de fundamentação histórica: lembrar o exemplo do que foi feito no passado, e evitar repetir os erros do passado e as distorções odiosas do modelo, que foi praticado e aplicado, em relação a esses mesmos estados, pelos antigos 'colonizadores' no passado - a construção de modelo novo se inscreve como possibilidade - as lições da história podem fazer sentido quando sejam aprendidas e sejam aplicadas;

(iii) economicamente a observância de modelo equilibrado de regência das trocas comerciais e das relações internacionais, pode autorizar o estado, vítima do passado, a se eximir, em decorrência do princípio da reciprocidade, da observância dessa regra em relação ao estado, responsável pela violação? Essa questão fundamental faz passar de problema de validade dos acordos comerciais, para problema de não-aplicação. Baste assinalar que essa questão põe em cheque o próprio fundamento das trocas comerciais. Tais regras, que deduzem sua fundamentação de ordem meramente determinada pela eficiência econômica, não podem ser, em toda e qualquer circunstância, vinculantes. A questão deve sofrer reavaliação e pode receber resposta negativa: como se dá na solução reconhecida em matéria do campo específico do direito humanitário: não se pode, simultaneamente, alegar o caráter absoluto de determinadas obrigações e, em resposta a violação destas, alegar base para se eximir de assegurar a observância e aplicação destas, pelo outro estado.

Nesse sentido, a concepção de modelo econômico internacional que se baseie no equilíbrio econômico, entre os parceiros comerciais, pode não fazer sentido, como estratégia de curto prazo: a possibilidade de um estado eximir-se da obrigação de aplicação desse modelo, decorrente de violação essencial de disposição deste, por outro estado, não é simples risco teórico. Mas pode e deve fazer sentido, quando pensado, como modelo de trocas comerciais, e de relações internacionais, não somente de caráter humanitário, e de cunho assistencialista, mas como estratégia, de médio e de longo prazo: constrói-se a estabilidade e a durabilidade da relação comercial, e das relações 
internacionais, por meio de parcerias econômicas, fundadas na reciprocidade de direitos e de obrigações, claro, como qualquer relação, mas também, sobre valores, e sobre o propósito de dotar o parceiro comercial, de instrumentos, aptos a consolidar patamares de desenvolvimento, mais consentâneos com a construção de desenvolvimento sustentável, entre esses mesmos estados.

\section{Modelo institucional e normativo para os BRIC}

A consolidação de modelos, legalmente justos e economicamente eqüitativos, não passa, no mundo atual, de mera possibilidade. Isso pode ser apontado em todos os quadrantes do mundo pós-moderno.

Esta construção, que combine eficiência e justiça, embora não seja utópica, será dificilmente realizável, enquanto os homens - e consequentemente, os agrupamentos de homens, organizados como estados - não mudarem a sua natureza. O que somente remotamente se pode esperar ver acontecer.

Embora possível, não ocorrerá por acaso, nem se dará por simples inércia, em qualquer outro contexto, como entre Brasil, Rússia, Índia, China e, quem sabe, também África do Sul, mas pode ser construída, entre esses países, na medida em que estejam interessados e comprometidos em construir modelo novo de regência e de ordenação de suas relações internacionais. Assim como se pode dar nas relações entre países da CPLP - a Comunidade de países de língua portuguesa, como destes com a China, ou nas mais variadas análises combinatórias das relações internacionais, no mundo contemporâneo.

Dado o caráter essencialmente inovador e transformador da adoção de modelo como o BRIC, somente em decorrência de engajamento consciente e firmemente aceito, poderá este projeto aceder ao patamar da realidade. Tal aceitação haverá de dar-se primeiro conceitualmente, para, depois, ser construída na prática. Se for viável, se poderá chegar a, com este modelo BRIC, pretender passar da retórica à realidade.

A instauração de modelo simultaneamente eficaz e eqüitativo de relações internacionais entre estes países pode ser desejável, mas terá de ser construída, com base em compromissos, entre tais estados estipulados, e que sejam, ademais, cumpridos, tudo isso lastreado na conviç̧ão da sua possibilidade e do interesse para todos os participantes.

Pode, assim, parecer dificilmente passível de ser implementado, mas, não por isso, impossível. Pode ser construído e os países em questão, Brasil, Rússia, Índia, China e, talvez, também a África do Sul, poderiam dar contribuição relevante, não somente para os próprios estados interessados, como para a fixação de modelo inovador de relações internacionais. Esse quadro BRIC pode ser canal e caminho para solução inovadora entre os participantes, que também traga elementos novos para as relações internacionais.

Esse modelo pode ser construído. Em parte, o trabalho já se encontra em curso. Resta, contudo, ver se e em que medida este se haverá de fazer com base em 
princípios de justiça, de eqüidade, e de alinhamento pelos ditames do Direito Internacional, e do desenvolvimento sustentável. Internamente aceitos e aplicados, como norteadores dos compromissos, internacionalmente estipulados, entre os participantes.

Ao menos se pode esperar que esse modelo seja viável, e possa ser implementado. Exigirá homens íntegros e líderes dotados de visão além do curto prazo, para que se possa implementar estratégia de duração além das próximas eleições ou crise econômica seguinte, neste nosso mundo conturbado, pela percepção da instabilidade e da mudança, como já percebiam e aplicavam SIMA QIAN, como outros autores, nas diferentes tradições, oriental como ocidental.

Exemplos como estes merecem e precisam ser meditados. Não somente pelos princípios do passado, mas também pelas lições que dos ensinamentos deles pudermos extrair para o presente e para o futuro.

A alternativa à mutação dos modelos de relações internacionais será a repetição dos erros do passado. Com o agravamento das conseqüências, decorrentes da crescente interdependência e da necessidade de institucionalização das relações, além dos estados, também dos demais agentes internacionais, como as organizações internacionais, as organizações não-governamentais, e a sociedade civil como todo, cuja crescente presença e relevância não mais podem ser negligenciados.

Os seres humanos, em sua considerável maioria, pouco olham e menos ainda vêem, além das coisas mais próximas e dos interesses mais imediatos; poucas vezes chegam estes a se configurar como interesses 'nacionais' - e muito menos ainda, como interesses 'cosmopolitas' e qualquer que seja o nível de preocupações com o estado e o futuro do planeta. $\mathrm{O}$ apelo popular da ONU e do Direito Internacional se reporta somente a minoria ínfima dos exemplares vivos e pensantes do planeta. Este modelo é antes construção teórica, do que apelo prático e se reveste de pouca ou nenhuma concretude, para a grande maioria da humanidade.

O tempo presente, ante a enormidade dos desafios comuns e das necessidades compartilhadas, em razão da crescente interdependência, exige coordenação de iniciativas, em graus muito maiores do que em outras eras, na qual os seres humanos finalmente se conscientizem, no sentido específico e indispensável de que pensem e vivam, no mundo e em função deste, tendo em vista a possível futura ordenação teleologicamente humana organização da vida, da política e do direito no planeta : a emergência de novos parâmetros de confrontação, que poderiam estar plantados, desastrosamente se vê aflorarem, neste início do século XXI, com total inconsciência, porquanto se parece negligenciar o dado elementar de que, levados adiante, representariam a aniquilação da humanidade.

Concretamente caberá ver se os BRIC se vão alinhar por modelo regido pelo culto da força como critério definidor de prioridades e de alinhamentos na ordem internacional, e pela política de poder, como critério definidor de alianças, nas relações 
internacionais, no contexto pós-moderno - o que parece provável dada a tônica dos discursos, individualmente considerados, bem como destes, enquanto colegiados - como, infelizmente, ilustra o teor da Declaração de Ekaterimburgo - e pode ser, assim, mais um, dentre tantos grupamentos, mais ou menos transitórios, no contexto internacional.

Por outro lado, se poderia esperar que a base de experiências passadas, no caso de cada um destes, houvesse espaço para não somente configurar os BRIC como agrupamento operacional, nas relações internacionais, mas a partir da experiência deste se pudesse conceber modelo novo de ordenação das relações entre estados, inscritos em modelo institucional e normativo inovador. Cabe, contudo, não tomar os nossos desejos pela realidade: aponta-se tal possibilidade, mas não se afirma seja esta a via a ser seguida. O que pode parecer pouco provável.

A pouca probabilidade de modelo institucional e normativo inovador para os BRIC se põe, concretamente, em razão da baixa estima de cada um destes estados pelo Direito Internacional, como ferramenta básica de operação e de consolidação de espaços, no plano extranacional. Se isso se pode perceber e apontar, em relação a cada um, tanto mais se haverá de ver como o caso no plano interestatal.

Pode haver coexistência pacífica entre Direito Internacional e relações internacionais? A contraposição e especificidades de enfoque de um e outra são objeto de muitas análises de tal possível coexistência pacífica? A concepção reducionista de Direito Internacional, somente quanto à sua função escritural, no sentido de reduzir a termo tudo o que seja regido, por relações de força ${ }^{54}$ na política e nas relações internacionais não pode ser aceita.

No Direito Internacional se pode apontar extenso e ponderado exame dos "princípios", ${ }^{55}$ para afirmar estar este em estágio de transição e de desenvolvimento, no sentido de que era essencialmente, segundo a expressão de Rivier (1896), o direito de coexistência pacífica dos estados, ${ }^{56}$ onde se fazia repousar todo o direito sobre os acordos concluídos entre estados. Segundo tal concepção do Direito Internacional clássico, os costumes, como os princípios gerais do direito, somente tinham força jurídica na medida em que sua validade fosse reconhecida pelos estados, ou seja, no fim das contas, pelo acordo.

${ }_{54}$ WIGHT, Martin. A política de poder. Trad. Carlos Sérgio Duarte. Brasília: Ed. UnB, 1985; Col. pensamento político, v. 67, cap. i, "potências', p. 15-20, cit. p. 15) : “A politica do poder é um termo coloquial para designar política internacional. (...) tem o mérito de apontar para uma verdade central a respeito das relações internacionais, ainda que deixe certas outras coisas fora de foco. Mesmo que possa ter outras nuanças, a 'política de poder' sugere as relações entre potências independentes, e consideramos esse estado de coisas como existente."

5s FAVRE, Antoine. Principes du droit des gens. Paris/Friburgo: Librairie de droit et de jurisprudence/Presses Universitaires de Fribourg, Suisse, 1974.

56 RIVIER, Principes du droit des gens. 2 v., 1896. 
A partir do fim da primeira guerra mundial a idéia da solidariedade de todos os homens e de todos os estados começa a ter influência crescente, na vida jurídica e política da humanidade. Esse movimento, interrompido pela ascensão dos regimes totalitários, e mantido em compasso de espera, durante as décadas da guerra fria, pode passar a ser a tônica do cenário internacional, em seu sentido mais amplo, a partir do contexto pós-moderno.

Pode parecer paradoxal, que essas mesmas guerras mundiais, em razão dos movimentos que criaram, nas massas e entre os governantes, fazem assumir viva consciência da realidade da comunidade universal: tornou-se manifesto que essa comunidade deve se organizar, dotar-se de regras de direito próprias para responder aos seus fins naturais de proteção e de desenvolvimento de seus integrantes. É o Direito Internacional da cooperação que viria se edificar.

A inserção do Direito Internacional em perspectiva histórica e cultural é essencial para a compreensão e fundamentação deste. Nesse sentido, D. Schindler $(1933)^{57}$ sugeria o estudo dos "fatores sociológicos e psicológicos" como contribuição para o Direito Internacional, P. E. Corbett $(1954)^{58}$ propunha "base social para o direito das gentes" e, T. Ruyssen (1939) ${ }^{59}$ as "características sociológicas da comunidade humana"

Por sua vez, J. Stone $(1956)^{60}$ examinava os "problemas confrontando análises sociológicas a respeito do Direito Internacional" e B. Landherr (1957) ${ }^{61}$ as teorias sociológicas contemporâneas face ao Direito Internacional pós-moderno.

O direito, como todo, e especificamente o Direito Internacional, se inscreve não somente como 'ciência' social, mas tem na diversidade a sua fundamentação intrínseca: a pós-modernidade não é inovação no Direito Internacional - este se faz a partir da fragmentação e da diversidade e, em meio a estas, tem de ser estruturado e poder se desenvolver. Muito embora o Direito Internacional pós-moderno somente torne mais patentes essas dimensões, ainda parecem ser incipientes o seu tratamento dessa forma, com a adoção de parâmetro efetiva e tautologicamente internacional.

A construção do Direito Internacional se fez como conjunto de princípios, que se traduziram, progressivamente, em conjunto de normas, que, por seu turno, se exprimiram mediante procedimentos internacionais. Nessa construção existe continuidade,

57 SCHINDLER, D. Contribution à l'étude des facteurs sociologiques et psychologiques du droit international. RCADI, 1933, t. 46, p. 229-326); D. SCHINDLER, mais de trinta anos depois, de volta à Haia, abordava, Aspects contemporains de la neutralité (RCADI, 1967, t. 121, p. 221-322).

58 CORBETT, P. E. Social basis of a law of nations. RCADI, 1954, t. 85, p. 467-544.

59 RUYSSEN, T. Les caractères sociologiques de la communauté humaine. RCADI, 1939, t. 67, p. 121-232.

60 STONE, J. Problems confronting sociological enquiries concerning international law. RCADI, 1956, t. 89, p. 61-180.

61 LANDHERR, B. Contemporary sociological theories and international law. RCADI, 1957, t. 91, p. 1-104, tb. em francês, Les théories de la sociologie contemporaine et le droit international. RCADI, 1957, t. 92, p. 519-628. 
existe sucessão histórica direta e ocorrem empréstimos recíprocos, entre autores e correntes do Direito Internacional desde os clássicos até o tempo pós-moderno.

Se o registro de juridicidade internacional no passado dos países BRIC pode não parecer tão promissor, ao menos cabe esperar que estes estados, ao estipularem entre si, novas alianças, não incorram nos mesmos erros do passado.

Celso Albuquerque Mello expunha (1984, publ. 1985) ${ }^{62}$ o papel e o peso, da divisão do mundo em blocos e dos alinhamentos automáticos, no interior destes, durante as décadas da guerra fria: “a sociedade internacional após a segunda guerra mundial apresenta algumas constantes e outras variáveis"

“O norte-sul é o conflito que maior número de modificações tem trazido ao Direito Internacional público. Este jamais esteve em vias de sofrer uma transformação tão profunda quanto no momento atual" observava C. D. A. Mello (1984, publ. 1985): "os doutrinadores dos países ricos que receiam o 'caos" costumam rotular o momento com que nos defrontamos de crise do Direito Internacional. Enquanto que, para os internacionalistas com uma visão do terceiro mundo, o 'caos' era o Direito Internacional clássico, que sempre permitiu a dominação e a expropriação dos pobres pelos ricos" 63

Lucidamente, embora ainda durante o período de vigência desse modelo, C.D.A. Mello apontava as fissuras e as inconsistências. ${ }^{64} \mathrm{~A}$ luta contra o colonialismo, que todo o terceiro mundo apoiou, sempre teve para os supergrandes uma razão fundamental: afastar a Grã-Bretanha e a França da posição de grandes potências.

A diferença ideológica entre os blocos capitalista e socialista não se manifestou no Direito Internacional. C. D. A. Mello considerava "suficiente recordar que os Estados Unidos da América aceitou um tratado afirmando que o princípio da coexistência pacífica é um dos princípios fundamentais das relações internacionais contemporâneas ${ }^{65}$, bem como que a mais recente obra de Direito Internacional público, publicada na União soviética e divulgada no Ocidente, coordenada pelo professor Tunkin ${ }^{66}$ afirma que o Direito

62 MELLO, Celso D. de Albuquerque Aspectos gerais do direito internacional público contemporâneo (XI Curso de derecho internacional, Rio de Janeiro, "organizado por el Comitê jurídico interamericano, con la cooperación de la Secretaria general de la OEA, en agosto de 1984", Washington: O.E.A.- secretaria general, 1985, p. 3-27).

63 Id. Ibid., p. 5-6).

64 Id. Ibid.: "Posteriormente temos a chamada ‘crise das alianças' em que a França denuncia o tratado sobre tropas da Organização do Tratado do Atlântico Norte e o conflito sino-soviético torna-se mais agudo. Finalmente continuamos com a existência de blocos mesmo que eles não tenham mais o aspecto monolítico que possuíam anteriormente".

65 Na linha da Res. 2625 (XXV) A.G.N.U., annex, Declaration on principles of international law concerning friendly relations and cooperation among states in accordance with the U.N. Charter (1970).

66 Adicionalmente é interessante ver a evolução do enfoque de G. I. TUNKIN, desde seu Coexistence and international law (RCADI, 1958, t. 95, pp. 1-82) até TUNKIN, G. Politics, law and force in the interstate system. RCADI, 1989, t. 219, p. 227-396; a obra mencionada por C. D. A. Mello (TUNKIN, G. et al. Curso de derecho internacional. Trad. do russo por Federico Pita, presentación de V. Jarlámov. Moscou: Editorial 
Internacional público não tem ideologia e que ele é simplesmente formado por normas de conduta e que para ele existir não é necessário que haja comunhão ideológica" 67

"Façamos um estudo desta matéria. É de se notar que ela é uma conseqüência da descolonização, ou seja, de acederem à independência países afro-asiáticos com líderes que têm uma cultura não cristã-ocidental e capitalista. O Direito Internacional que estes países encontraram regendo a sociedade internacional não atendia aos seus interesses". Por isso, segundo apontava C. D. A. Mello, "reivindicações são formuladas, especialmente nas organizações internacionais e dentro delas, na Assembléia, ou Conferência, isto é no órgão onde há uma igualdade entre os membros e onde todos os Estados estão representados. Eles são o terceiro mundo que, como já foi assinalado do 'terceiro estado' da Revolução francesa, reivindicam o direito de participar nas decisões, que vão reger as relações internacionais"

"De qualquer modo, é necessário assinalar que nem sempre há, por parte do denominado terceiro mundo reivindicações uniformes e homogêneas. Pelo contrário, devido à multiplicidade de ideologias, sistemas políticos e econômicos eles não formam um bloco unido, isto é, que possa exercer uma pressão eficaz. Em conseqüência, há uma politização do Direito Internacional, devido ao afrontamento entre os dois Direito Internacional, o clássico e o novo. Significa isso que está morrendo o Direito Internacional sem que surja um novo. O terceiro mundo domina as comissões que elaboram o Direito Internacional, como a Comissão de Direito Internacional, a Comissão de direito comercial internacional, o Comitê do fundo dos mares e UNCTADs. É de se observar que tais comissões não têm o poder de decidir, no sentido jurídico, isto é, de aprovar normas que serão obrigatórias. Assim, o método utilizado por tais países tem sido a aprovação de declarações, recomendações, as quais têm um valor político e moral. Acresce, ainda, que elas dão legitimidade às reivindicações desses estados, ou, talvez, venham a se transformar, no futuro, em costume internacional. O velho problema do Direito Internacional, que não desenvolveu critérios precisos para distinguir o jurídico do não-jurídico, é agravado no atual momento histórico" 68

Progreso, 1979. 2 v.).

${ }^{67}$ MELLO, C. D. A. (op. cit., Washington, 1985, loc. cit.): "Esta posição que nos parece realista é também de um certo modo uma ironia, vez que foi o marxismo quem salientou e defendeu, a meu ver acertadamente, o caráter ideológico do direito. Enfim, as atitudes dos Estados Unidos da América e da União soviética, bem como de seus aliados, são profundamente semelhantes, vez que as suas posições e interesses, na sociedade internacional, são semelhantes. Ambos procuram conservar a posição hegemônica que têm e, através de conflitos localizados, aumentar a sua área de influência, sem que haja maior risco de ambos se confrontarem diretamente.

68 MELLO, C. D. A. (op. cit., Washington, 1985, p. 6-7) enfatiza ter sido a intenção, ao expor os dois grandes cortes na sociedade internacional, "chamarmos a atenção para a relatividade do que vai ser exposto, no sentido de que o jurídico se confunde com a política; o aspecto técnico com o ideológico. Não pretendemos com isso afirmar que tenha sido possível, em algum momento histórico, existir um direito sem aspecto político e, em conseqüência, ideológico. O que sustentamos é que atualmente esse aspecto surge, de modo 
Justamente não é o dado menos interessante do Direito Internacional o fato deste comportar grande número de questões controvertidas. Agregue-se a isso o período de transição vivido pelo Direito Internacional, também como período de experimentação, mostrando o Direito Internacional em ação nas instituições e nos mecanismos de implementação : a ênfase na atuação da Corte Internacional de Justiça, da sistematização do Instituto de Direito Internacional e da reflexão da doutrina. A sistematização das práticas dos estados muitas vezes dependerá das amostragens feitas pelos seus representantes nacionais. Caberá, inexoravelmente, indagar: até que ponto tais não serão seletivas ?

A convivência entre o velho e o novo modelos de ordenação da convivência entre estados nem sempre é pacífica. Simultaneamente há recorrências ou avanços, seja em sentido positivo, rumo a institucionalização crescente, que poderia levar de Direito Internacional da cooperação para Direito Internacional da integração; seja em sentido negativo, tendendo a negar os pressupostos e a validade de qualquer regulação legal da convivência entre unidades políticas soberanas, reduzindo a interação entre estados às relações de força e equilíbrio de terror, baseado na ameaça e no uso da força.

Dentre os BRIC cabe ver, ao lado das semelhanças apontadas, bem como das interações possíveis, a medida na qual as especificidades históricas poderão ter impacto sobre o modelo e a forma de buscar a tão almejada e tão falada inserção internacional. Como em outros campos, a história terá o seu peso e o seu papel para se compreender o quadro atual, bem como, a partir deste, ensaiar algumas projeções para futuro próximo.

Diversamente de Rússia, Índia e China que foram impérios e têm mais ou menos claramente enunciadas pretensões hegemônicas, o Brasil foi "império" de 1822 a 1889, e pacífico, exceto pelas críticas que se façam à condução da guerra do Paraguai. Mas, mesmo nesta, mais do que guerra de agressão, tratou-se de defesa.

De tempos em tempos afirma o Brasil pretender exercer liderança regional, liderança essa que os vizinhos se apressam em aduzir nunca terem aceitado nem delegado tal função ao nosso país. Quanto disso se sustente, além do entusiasmo passageiro - e custoso - de sediar uma olimpíada ou um campeonato mundial de futebol veremos a partir dos próximos anos.

Alguns dados, contudo, merecem ser enfatizados. O Brasil, salvo algumas correntes nacionalistas extremadas, porém minoritárias, que apregoam ou alegam temer certo 'imperialismo' nacional, não parece ameaçador, nem o é de fato.

Diversamente de Rússia, Índia e China, não somos potência nuclear. Isso nos traz percepções positivas e negativas, mas é parte da realidade.

acentuado, sem qualquer máscara, que tente ocultá-lo, e talvez devido à universalização da sociedade internacional ele seja mais acirrado" 
Diversamente de Rússia, Índia e China, não fomos nem somos império - no sentido "imperial" do termo - e especificamente de ter exercido dominação sobre territórios ancilares, que se nos fossem submetidos pela força. Exceto pela Província Cisplatina, o atual Uruguai, de 1821 a 1828, onde a Assembleia nacional de lá votou unirse ao Brasil, e a separação teria resultado antes de pressão da Argentina, que de vontade manifestada pela população uruguaia.

Diversamente de Índia e China, não fomos humilhados por ocupação estrangeira, colonial ou equivalente, até passado recente. Isso deixou fortes marcas em ambos: China e Índia têm ainda de completar a catarse dos traumas do passado, para estabelecer a relação com o "mundo ocidental" de modo menos pautado pelo desejo de afirmação de força.

A herança do período colonial inglês é tratada de modo conturbado na Índia, até os dias atuais. A China mostra quanto ressentimento conserva, ao se completarem sessenta anos da "data nacional" 1949. Desde esse marco, quando se instaura o regime que lideraria até a sua morte MAO Ze Dong e, com alguns ajustes mantém desde então os seus sucessores, vem a China festejar a sua condição de potência emergente sem disfarçar as suas intenções e pretensões.

As humilhações sofridas pela China, tratada como terra de ninguém, na segunda metade do século XIX e na primeira metade do XX, não foram e não serão facilmente esquecidas. Esse dado não deveria ser esquecido por europeus e estadunidenses quando com esta dialogam e negociam.

Ainda mais a Rússia que, por sua vez, não somente foi a outra super potência, nos quarenta anos da assim chamada guerra fria (1949-1989), e antes disso como império expansionista, liderado pela família Romanov, durante cerca de trezentos anos, e mesmo antes destes, foi a potência hegemônica que se estendeu "colonialmente" mas o fez sem descontinuidade geográfica, de modo extenso e substancial, sobre a Ásia central, sobre a região do Cáucaso, bem como depois de abranger até os confins da Sibéria, atravessam os russos o estreito de Behring, e se estendem ao Alasca, e lá permanecem até que esse território seja comprado pelos Estados Unidos, no início da segunda metade do século XIX. Mesmo se teve a Rússia acentuada queda política, militar e econômica nos últimos vinte anos, e esta se acentuou de modo brutal no último ano, a partir da crise financeira mundial de setembro de 2008, que se estima teria levado cerca de um quarto da população russa para baixo da linha da pobreza, claramente não parecem os russos ter perdido a lembrança e a visão do imperial passado, sob a égide da águia bicéfala, e da pretensão de serem a "terceira Roma"

A nossa herança colonial se diluiu há quase duzentos anos, e ficou para trás. Dificilmente se poderá dizer ter ocorrido de modo traumático. Isso pode ser considerado sob tripla perspectiva, política, econômica e cultural. 
Politicamente a diluição da condição colonial brasileira se pode contar quer a partir da transferência do centro de poder de Portugal para o Brasil, em 1808, ou da elevação do Brasil à condição de Reino unido com Portugal e o Algarve, em 1815, ou formalmente, em 1822, ou ainda, por meio do tratado de Lisboa de 1825, quando a antiga metrópole aceita o fato da independência e a partir daí se abre o caminho para o reconhecimento do Brasil como sujeito de Direito Internacional, e a inserção nossa no fechado e reacionário cenário interestatal da época, regido pelas diretrizes emanadas do concerto europeu, que rege o modelo internacional do fim das guerras napoleônicas, em 1815 , até o momento em que eclode a primeira guerra mundial, em 1914. De qualquer desses pontos de partida, teremos cerca de duzentos anos desde então transcorridos, e não se poderá pretender seja esta uma componente traumática de nossa história. Antes é vista com bom humor e com certa ironia, do que como carga pesada que oneraria o inconsciente coletivo nacional.

Econômica e culturalmente a desvinculação colonial terá sido menos clara. E menos fortemente assinalados os marcos delineadores dos resultados. Econômica e culturalmente ainda se vêem recorrências de nossa autopercepção como "colonizados" quando nos comportamos como colonizados.

A condição colonial se pôs, depois de rompidos os laços coloniais propriamente ditos com Portugal, no plano econômico, durante o século que se segue à independência, mais precisamente até 1926, com a preeminência da hegemonia britânica no Brasil. Entre nós, o ano de 1926 assinala a passagem da hegemonia econômica do Reino Unido para os Estados Unidos.

Em nossa relação com os Estados Unidos esse viés quase colonial em boa medida se mantém desde então, mesmo se substancialmente atenuados os volumes de investimento estrangeiro direto, e muito diversificadas, nas últimas décadas, a procedência de capitais, pela crescente importância de investimentos provenientes de diferentes países europeus - capital alemão, espanhol, português, como também francês e de outros integrantes da União Europeia entre nós - como também de outros países, como se dá no caso do investimento japonês e das importantes relações entre Brasil e Japão, nos mostraram as comemorações do centenário da imigração japonesa, em 2008.

Culturalmente oscilamos entre a afirmação da identidade nacional e a cópia indiscriminada de modelos estrangeiros, muitas vezes sem razão de nestes se buscar melhor qualidade ou adequação. O que, muitas vezes, se faz em detrimento das soluções nacionais adequadas. Talvez baste um exemplo para ilustrar o ponto de vista : a arquitetura brasileira existe e tem excelente qualidade, como se viu na arquitetura modernista, como tivemos, dentre outros G. Warchavik, Oscar Niemeyer e Franz Hepp, e temos Paulo Mendes da Rocha e Isay Weinfeld, por exemplo, mas, ao mesmo tempo se copiam e se multiplicam Ersatz, de gosto duvidoso e de origem espúria, de arquitetura de segunda 
classe e destituída de estilo e de originalidade, quiçá talvez proveniente de Miami, nessas inomináveis construções de neoclássico com vidro espelhado azul. O país que já teve arquitetura própria aceita e convive com tais aberrações. Alega-se ser isso o que vende e o que o público quer. Mas, felizmente se vêem algumas exceções.

Serve o exemplo para mostrar como se faz a dependência em relação a copiarmos coisas das quais não teríamos necessidade, porque teríamos parâmetros e modelos que poderiam ser considerados, revisitados, inovados. Faz-se porque se faz, quase sem nos darmos conta de quanto nos deixamos colonizar, de modo por vezes tolo, inconsciente e inconseqüente, sem motivo, sem ganhar por isso.

O Brasil seria o menos ameaçador e o menos hegemônico dos quatro BRIC. Digo-o, no momento, em relação aos quatro, porquanto a África do Sul tem os seus sérios problemas estruturais internos a solucionar. Esta não se exclui da equação BRIC, mas simultaneamente a sua plena inserção neste não está claramente esboçada nem encetada.

De um lado, a multiplicação de esforços paralelos pode ser espaço de flexibilidade e de multiplicação de escolhas e de canais possíveis de construção da interação com outros estados, para o fortalecimento das agendas próprias, por meio de ações conjuntas coordenadas no plano internacional. De outro lado, entre BRIC e IBAS não existem diferenças de conceitos estruturais, nem tampouco de objetivos que impossibilitem a implantação de estratégia conjunta BRIC + IBAS = BRICAS.

A possibilidade de conjugação dos esforços BRIC mais África do Sul pode servir para reforçar a mesma dinâmica, e ao mesmo tempo abranger parceiro de outro continente, em relação ao qual o Brasil alega e a China claramente se empenha em construir laços e fortalecer de modo acelerado a sua presença e peso próprios. Superados os óbices internos sulafricanos, que tornavam quase estanque o diálogo desta com os vizinhos do continente, pode a perspectiva BRIC, ao abranger a África do Sul conquistar dimensão mundial e repercussão simultânea em quatro continentes.

Seria justamente o Brasil aquele que pode alavancar a difusão do modelo BRIC e mostrar essa perspectiva. Com os menores riscos relativos de parecer hegemônico e ameaçador.

Logicamente a perspectiva BRIC ainda está por fazer. Quer interna, como na projeção externa. E cabe esperar se faça em futuro não muito remoto, porquanto o mundo muda rapidamente à nossa volta, e a busca da inserção internacional se faz de modo dinâmico e constante, em cenário mundial pautado por mudanças muito rápidas nas últimas décadas e que devem ainda mais se acelerar nas próximas.

Conclusão

O caráter inovador da perspectiva BRIC está justamente no fato de que estes países podem cuidar de si e ao mesmo tempo formular modelo novo de inserção 
internacional e de cooperação. A perspectiva está colocada. Será, a seguir preciso passar para a implementação desta.

Quanto poderá efetivar-se o modelo BRIC ainda terá de ser visto nos próximos anos. Mas a viabilidade do modelo está claramente colocada. Claramente colocada também a condição essencialmente inovadora que pode ter esse modelo entre os participantes, bem como para se redesenhar o conjunto das relações internacionais no contexto pós-moderno.

São Paulo, janeiro de 2010. 